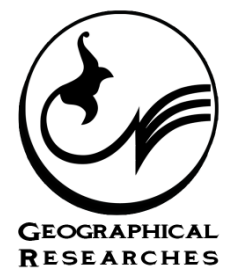

\title{
An Analysis on the Urban Identity Element of Sabzevar with Emphasis on the Views of Citizens
}

\section{ART I C L E I N F O}

\section{Article Type}

Original Research

\section{Authors}

Hajari F. ${ }^{1} M A$

Zanganeh Y.* $P h D$

Hamidiyan A. R. ${ }^{2} P h D$

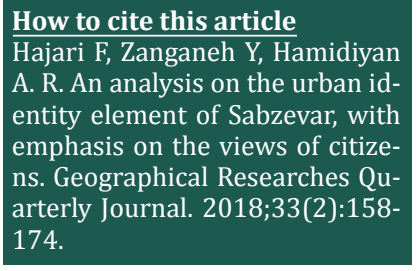

How to cite this article Ajari F, Zanganeh Y, Hamidiyan emphasis on the views of citizens. Geographical Researches Qu174.

\begin{abstract}
A B S T R A C T
Introduction and Background The issue of identity in general and urban identity in particular has a great importance because of the role that play in recognizing individuals, objects, communities and places. In spite of the importance of this issue, urban identity crisis is alarming in recent times. Natural elements, physical and socio-cultural components are three main elements identifying that conditions and characteristics of each of them determining their role in the identity of the city.

Aims The main purpose of this study is investigate and identify the urban identity component of Sabzevar with emphasis on identifying the mentioned factors by citizens.

Methodology This research method was of descriptive-analytic type. The data were collected through a document (library) method and a survey (questionnaire) method. The statistical population has been people over 15 years old of Sabzevar, who had been residence in this city for at least 5 years. The research units is Individual and samples are obtained using by Cochran formula a sample of 384 people.

Conclusion The results show that on the basis relative frequency of recognized elements by the respondents, according to the group of synthetic and physical components with 44.21 percent, natural components with 30.29 percent and the human factor (25.49 percent) to be accounted as the most significant components of identity of Sabzevar city. Also citizens place attachment as one of elements of identity which is more than average level. Another result of this study is that among the 30 physical element of streets, squares and parks named by respondents, with the exception of 2 cases that are located in the city new part, the rest have taken place in old and central mid regions. In addition, these results indicate that there is no significant difference between the knowledge of residences regarding identity elements of physical and built environment of the city.
\end{abstract}

Keywords Sabzevar; Urban identity; Local Identity; Place Attachment; Views of Citizens
${ }^{1}$ Department of Geography and Urban Planning, Hakim Sabzevari University, Sabzevar, Iran *Department of Geography and Urban Planning, Hakim Sabzevari University, Sabzevar, Iran ${ }^{2}$ Department of Geography and Urban Planning, Hakim Sabzevari University, Sabzevar, Iran

\section{*Correspondence}

Address: Department of Geography and Urban Planning, Hakim Sabzevari University, Sabzevar, Iran

Phone: -

Fax: -

yz1345@gmail.com

\section{Article History}

Received: August 14, 2018

Accepted: July 14, 2018

ePublished: September 17, 2018

\section{I T A T I O N L I N K S}

[Alikhani; 2007] Identity and identity crisis ...; [Barreto \& Ellemers; 2000] You can't always do what you want: Social identity and self-presentational determinants of the choice to work for ...; [Behzadfar; 2011] The identity of city; A look at the identity of ...; [Bell \& De-Shalit; 2011] The Spirit of Cities, Why the Identity of a City Matters in a ...; [Berger; 2016] Place, Imaginary, Identity: Place...; [Brocato; 2006] Place attachment: An investigation of environments and outcomes in a service ...; [Cheshmehzangi; 2015] Urban identity as a global ...; [Gharab; 2011] Urban ...; [Ghasemi Esfahani; 2004] Where are we from, identity ...; [Habib, et al; 2008] Subordinate questioning in urban ...; [Hayati; 2010] Evaluation of identity components of urban ...; [Landry \& Murray; 2017] Psychology \& the City: The Hidden ... [Lewicka; 2008] Place attachment, place identity ...; [Lynch; 1995] City view ...; [Manzo \& Perkins; 2006] Finding common ground ...; [Murzyn-Kupisz \& Gwosdz; 2011] The changing identity of the ...; [Nientied; 2018] Hybrid urban identity—the case ...; [Nofel, et al; 2009] Investigation and evaluation of ...; [Noqrekar, et al; 2009] An Introduction to Islamic Identity in ...; [Payton; 2003] Influence of place attachment and social capital ...; [Piran; 2005] The identity of cities; A great melee for ...; [Qaraee; 2008] A comparison of the viewpoint of public ...; [Rezazadeh; 2010] The Role and Function of Urban ...; [Riza, et al; 2012] City branding and ...; [Sabri \& Sharzadeh Mehrabi; 2006] The Position of the Concept of Identity ...; [Sajjadzadeh; 2013] The role of attachment to place ...; [Shajeie; 2015] Forgotten identity in historical fabrics...; [Singer; 2010] Psyche \& the city, a Soul's guide to the modern ...; [Williams, et al; 1992] Beyond the commodity metaphor ...; [Zanganeh; 2002] An analysis of the factors affecting ... [Zanganeh, et al; 2014] The impact of place spending and ...; [Zarghami \& Aminian; 2012] Urban identity and landscape ... 
Hajari F. MA

Zanganeh Y.PhD

Hamidiyan A. R. PhD

zangane@hsu. ac.ir

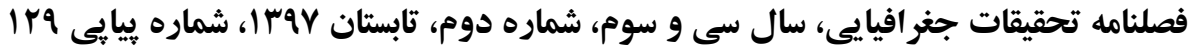

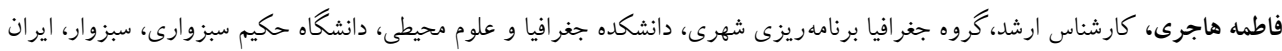

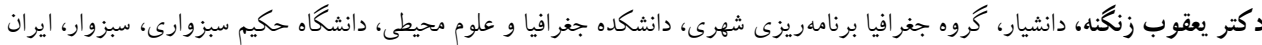

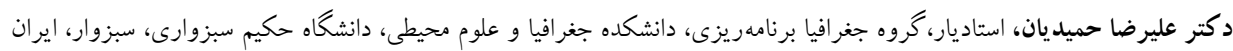

\title{
تحليلى بر عناصر هويتبخش شهر سبزوار با تأكيد بر ديدكاه شهروندان
}

\author{
يذيرش نهايى:MV/F/RT

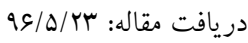

DOI: $10.29252 /$ geores.33.2.158

جكيده

مقدمه: موضوع هويت بهطور عام و هويت شهرى بهطور خاص ازجمله مقولاتى است كه به دليل نقشى كه در شناخت افراد،

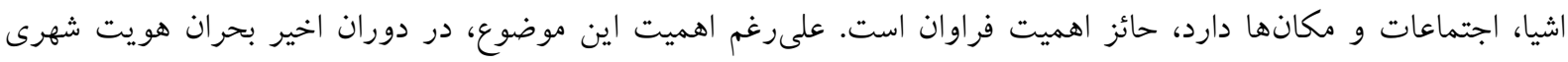

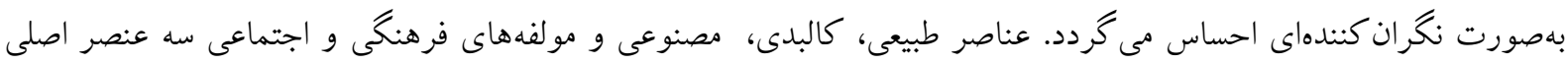

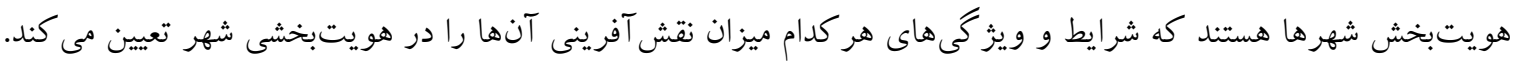

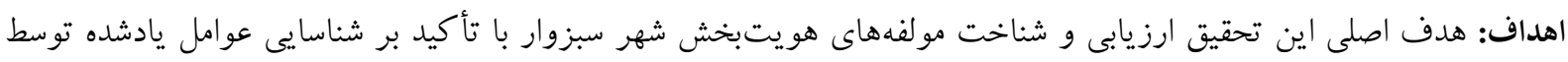
شهروندان است.

مواد و روشها: اين تحقيق از نوع توصيفى - تحليلى و روش گردآورى اطلاعات به دو روش اسنادى (كتابخانهاى) و ويمايش

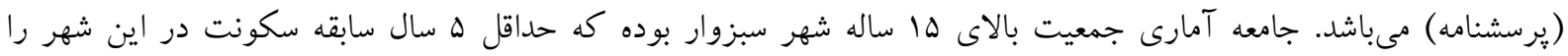

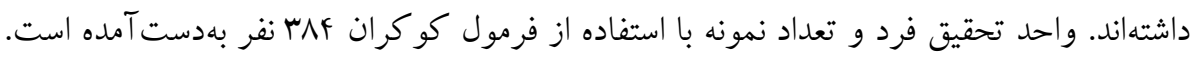

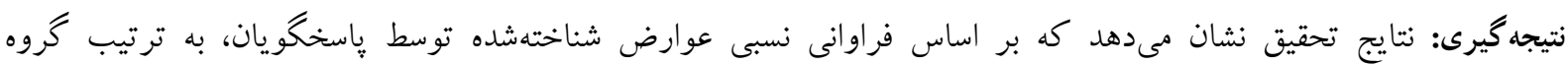

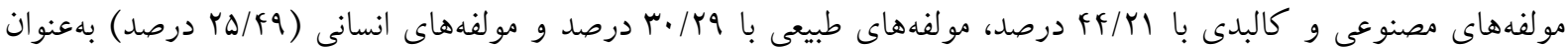
بارزترين مولفههاى هويتبخش شهر سبزوار محسوب مىشوند. همجنين سطح تعلق مكانى شهروندان بهعنوان يكى ديخر از از

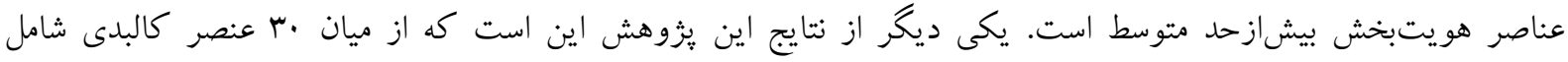

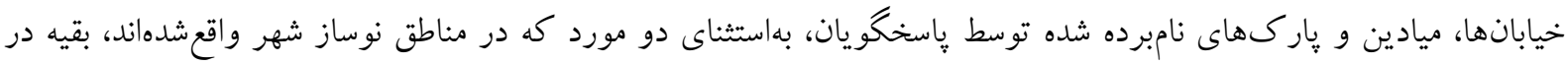

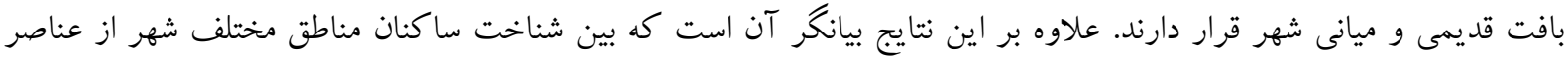
هويتبخش كالبدى و مصنوع شهر، تفاوت معنادارى وجود ندارد. وازگان كليدى: سبزوار، هويت شهرى، هويت مكانى، تعلق مكانى، ديدگاه شهروندان

مكان، محل و سرزمين براى مردم بسيار اهميت دارند، هراكه آنها توانيى هويتسازى بسيار بالايى دارند. مكان و فضا

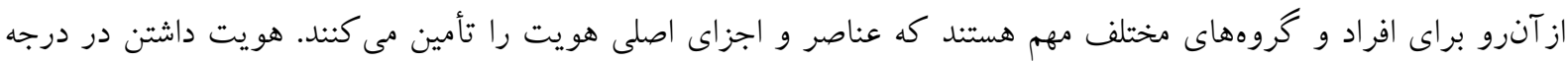

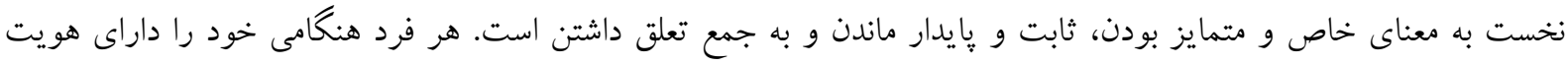




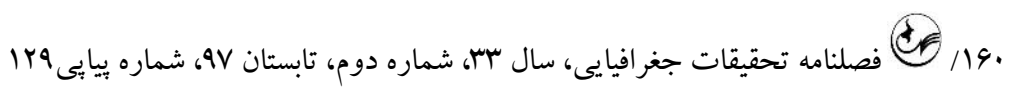
مىداند كه از تمايز، هايدارى و در جمع بودن خود اطمينان حاصل كند. مكان و فضا مهمترين عواملى هستند كه اين نيازهاى

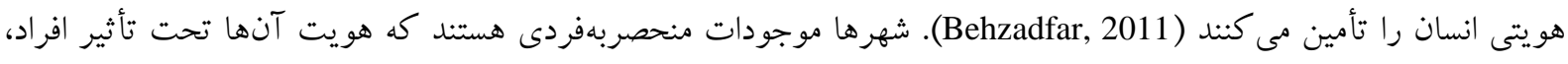

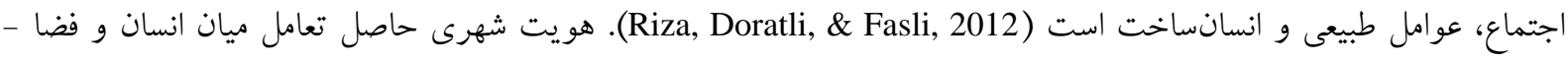

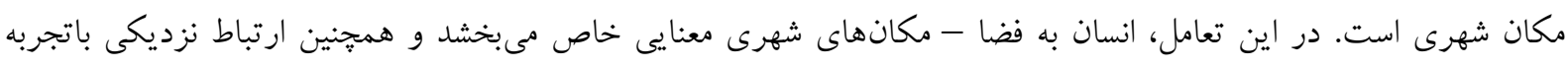

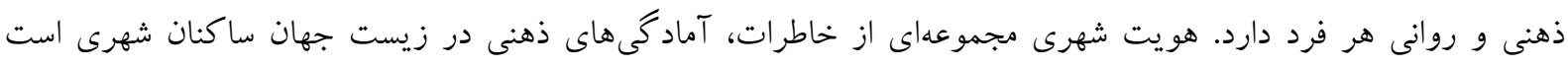

.(Gharab, 2011)

امروزه هويت شهرى ما، همجيون حلقه گمشده است و شهرها نه بر پائه هويت اصيل خود، بلكه بر خاية تقليدهاى بدون

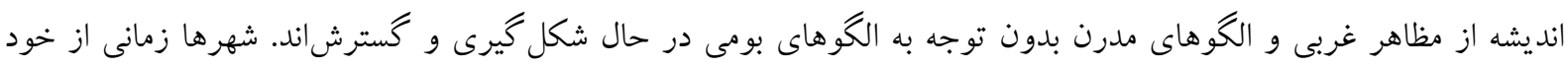

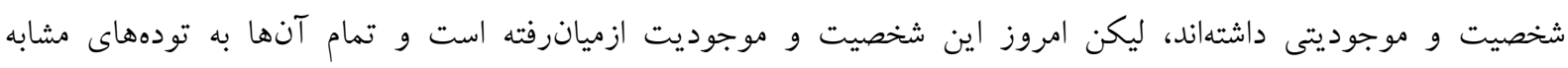

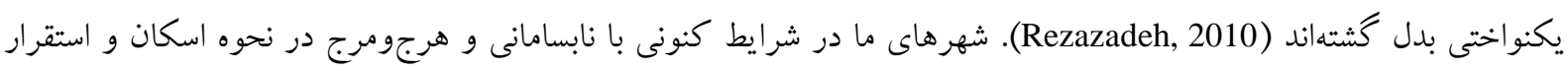

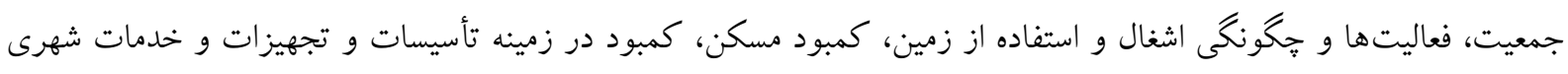

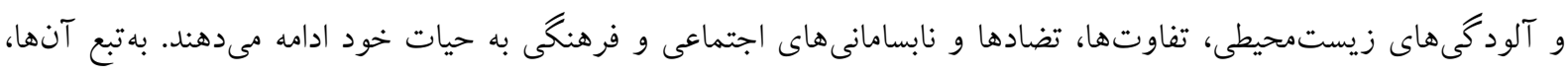

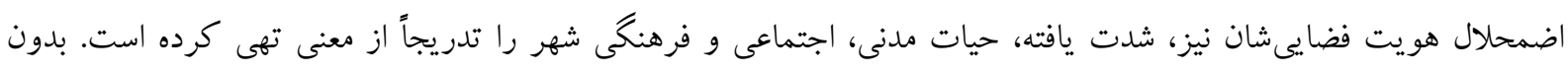

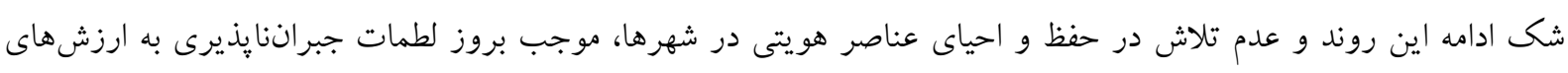

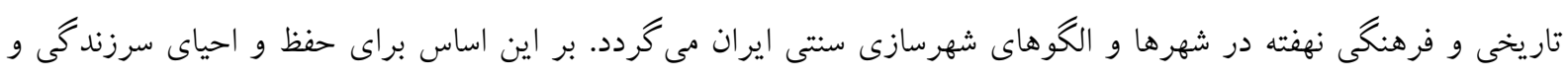

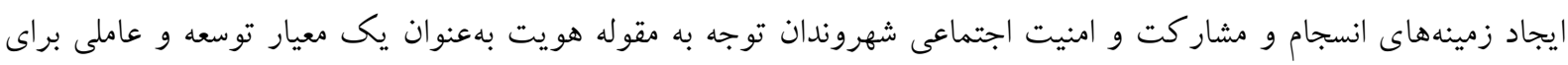
ارتقاى كيفيت محيط شهرى ضرورت ييدا مى كند.

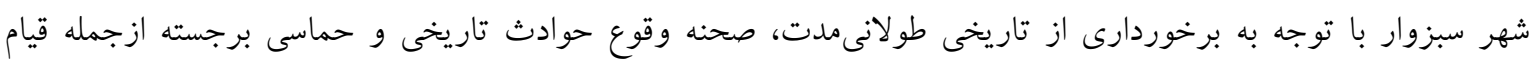

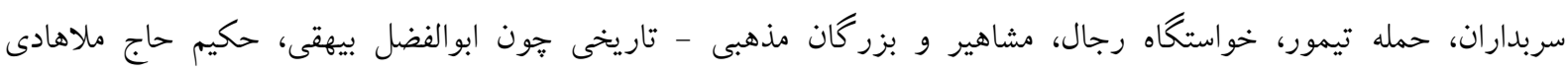

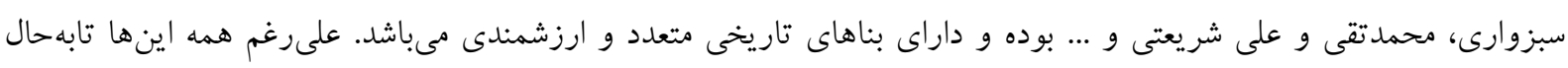

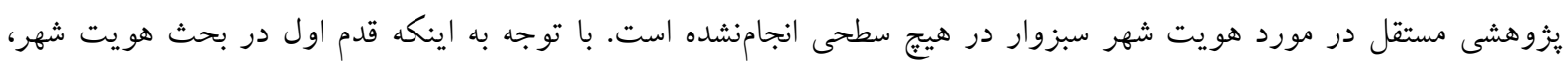

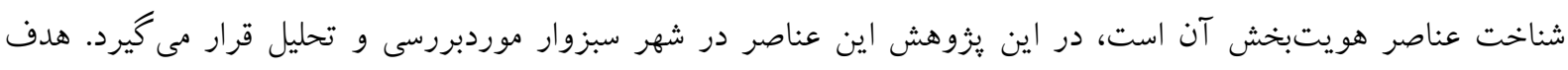

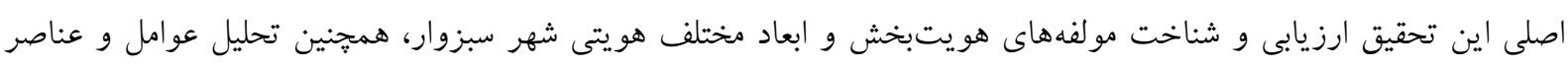

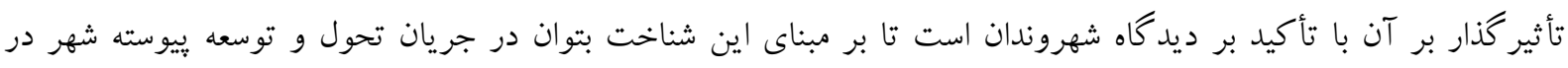

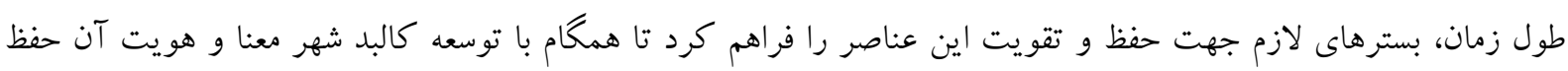

\section{بيشينه تحقيق}

تحقيقات متعددى در رابطه با هويت شهرى انجامشده است. كوييز و كوسدز 'در تحقيقى در مورد تغيير هويت در شهرهاى

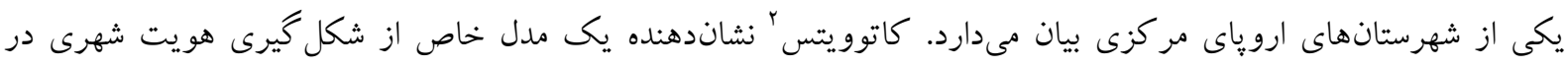

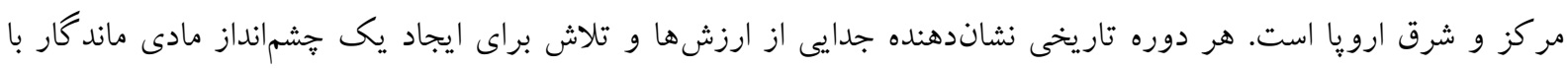

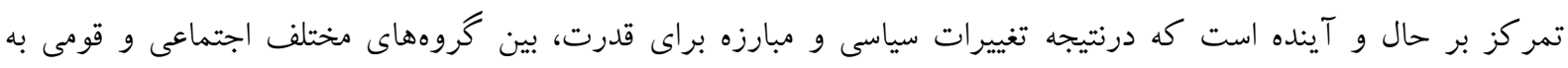




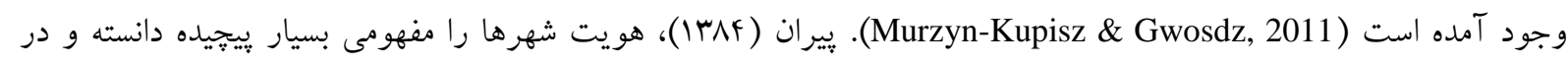
مقاله خود ضمن واكاوى معنا و مفهوم هويت و هويت شهرى به معرفى ابعاد و عناصر هويت مكانى (شهرى) يرداخته است. او هو

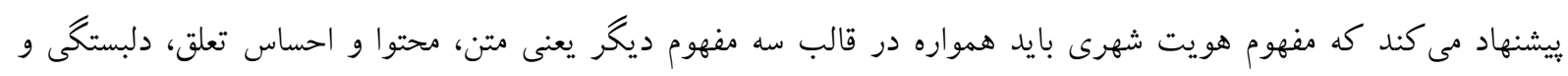

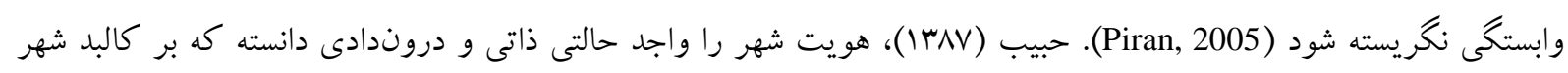

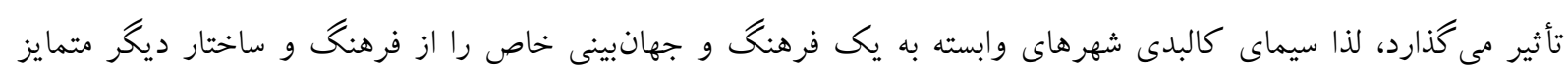

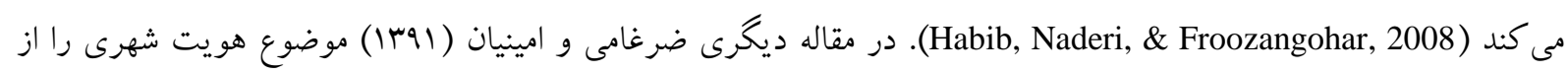

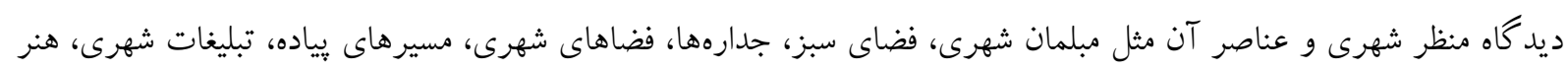

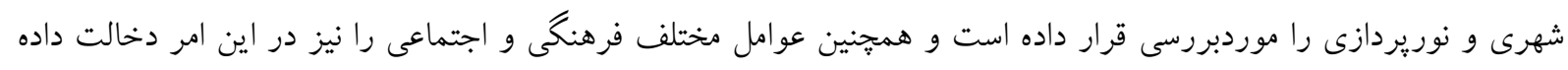

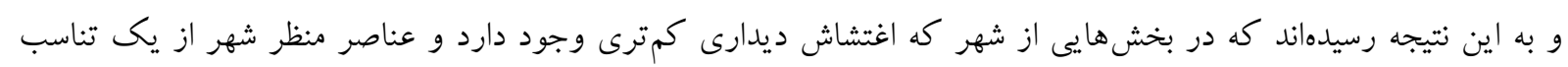

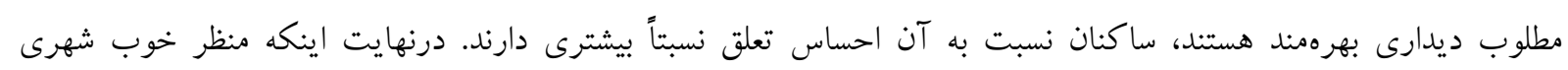

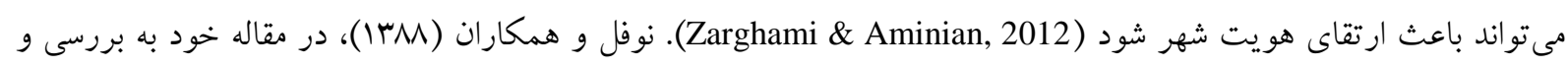
ارزيابى شاخصهاى مؤثر در هويت شهرى (نمونه موردى محله جلفا در شهر اصفهان) بر مبناى مطالعات ميدانى و تطبيقى

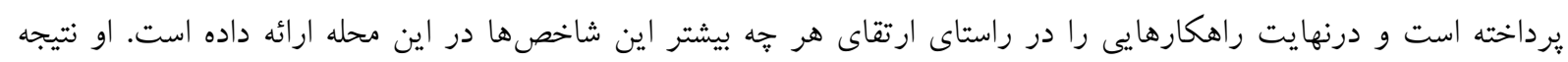

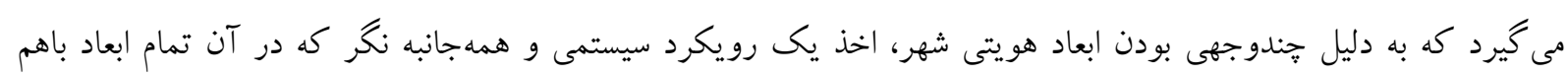

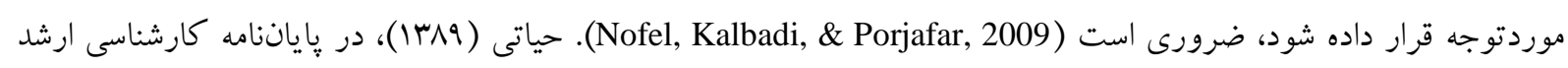

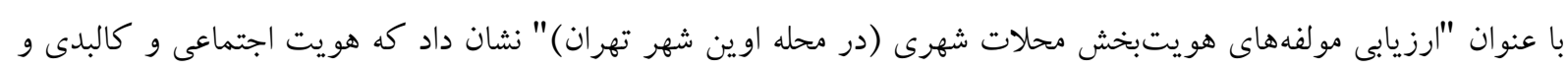

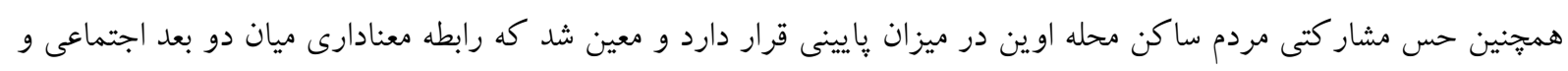

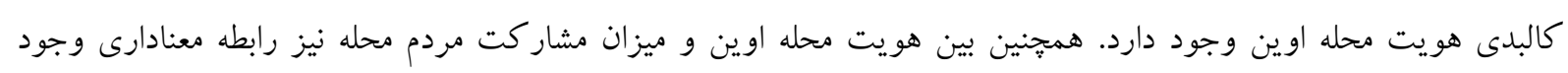

داشته است (Hayati, 2010).

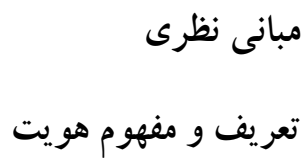

در تعاريف ارائهده از هويت بهطور عام غالباً با دو موضوع متقابل برخورد داريم. هويت از يكسو منحصربهفرد بودن و

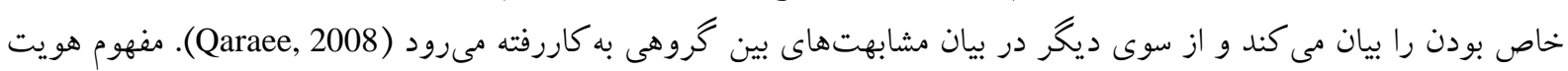

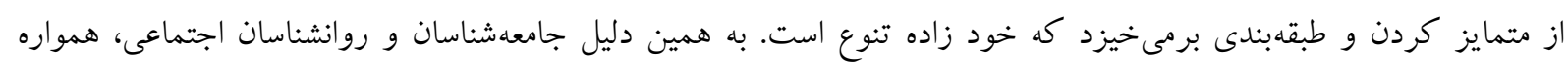

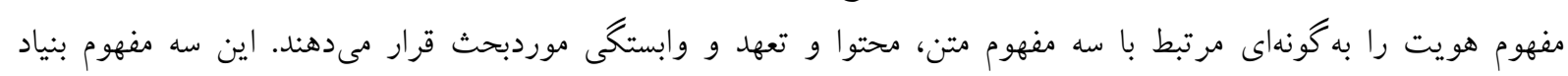

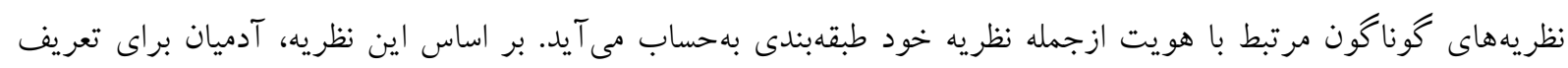
هويت خود از گروه، آنهم در مقام مقايسه با ساير گروههاى استفاده مى كنند (Barreto \& Ellemers, 2000).

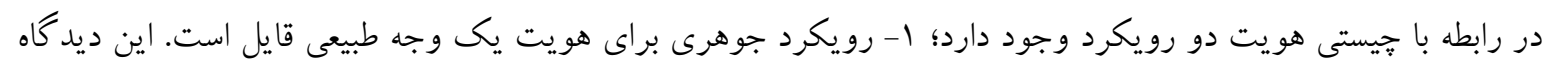

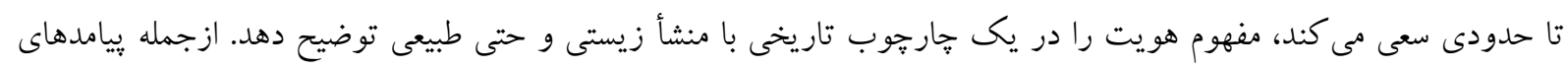

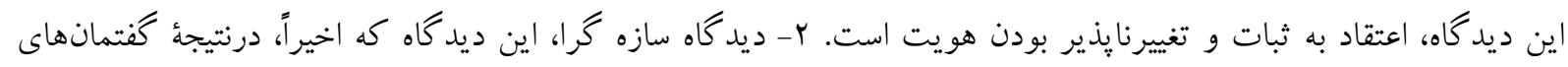

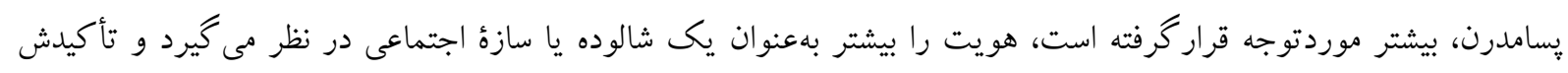




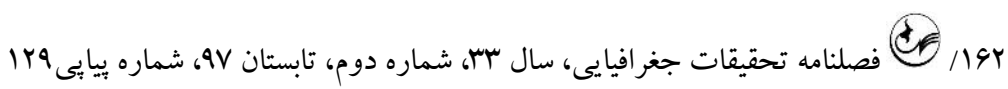
بر اين است كه هويت جنبة ذهنى دارد و نه طبيعى. بر مبناى اين تلقى از هويت، هويتها در جريان مراودات و آميزشهاى اجتماعى شكل مى گيرند (Alikhani, 2007). يكى ديخر از معانى هويت كه علاوه بر برخى رهيافت هاى فلسفى، بر فهم عمومى و عاميانه آن استوارشده الاهيت و

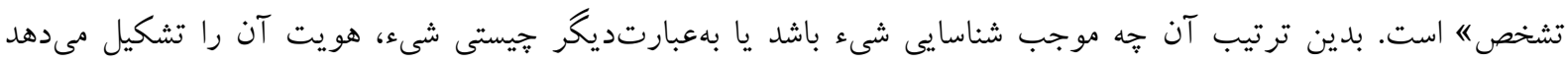
(Noqrekar, Hamzehnegad, \& Ranjbar Kermani, 2009). النها پديدهاى كه دغدغه هويت دارد، انسان است و همواره به

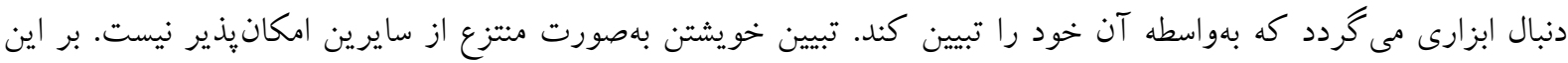
مبنا دستيابى به هويت شخصى نيز تابع يك فر آيند اجتماعى استه (Ghasemi Esfahani, 2004). هويت مكانى مكان نيز مى تو اند متمايز كننده و هويتبخش باشد. بر اين اساس مفهومى به نام هويت مكانى شكل مى گيرد. هويت مكانى

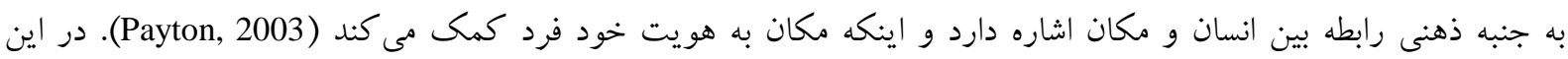

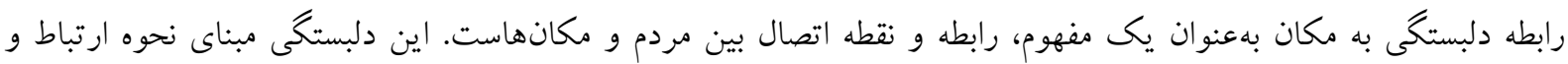

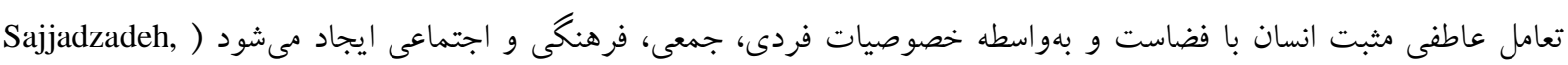

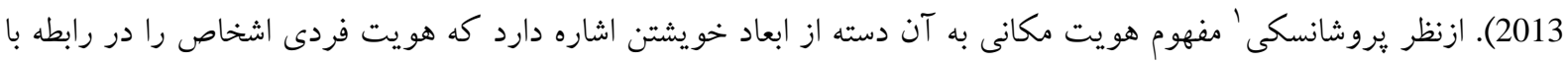

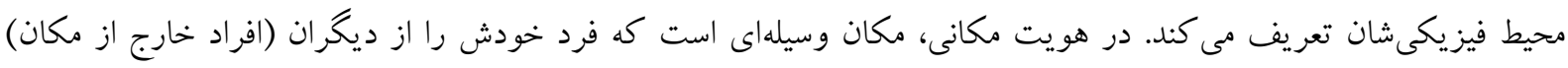

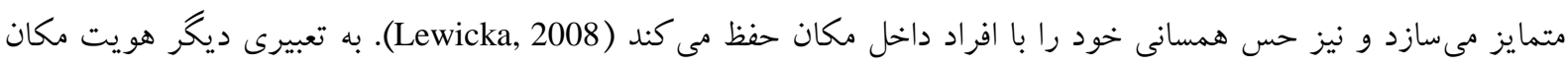

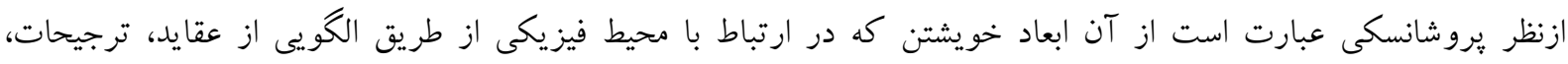

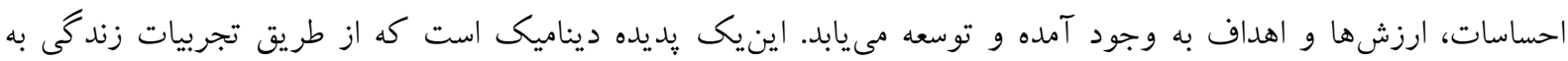
وجود مى آيند و تبديل مىشوند (Manzo \& Perkins, 2006).

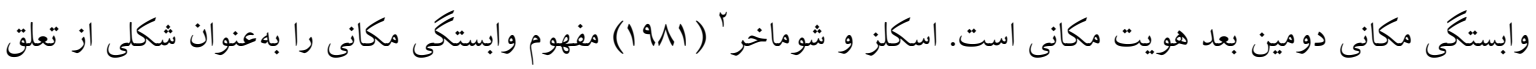

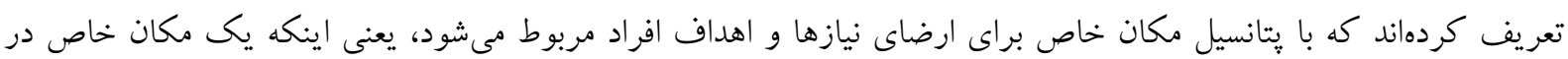

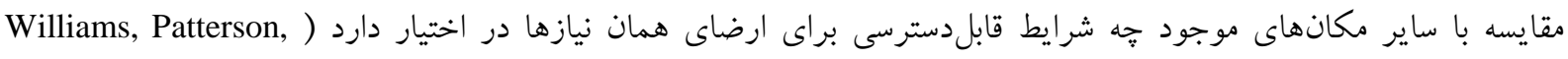
Roggenbuck, \& Watson, 1992

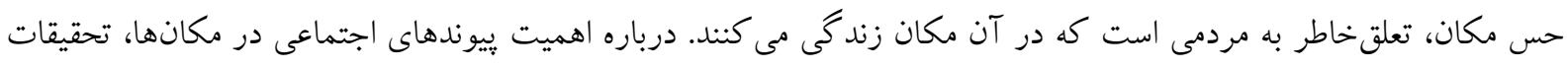

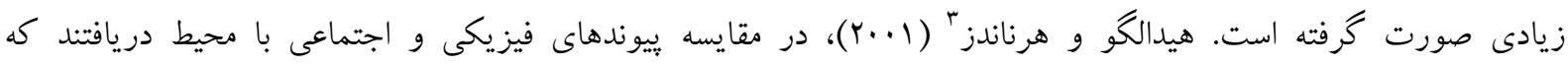

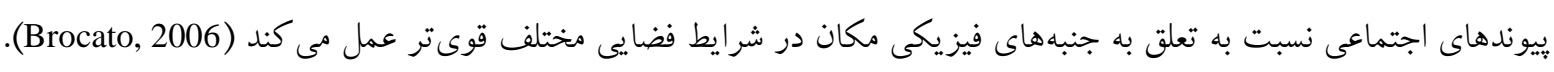

شهر و عناصر و اجزاى آن بهعنوان مجموعهاى از عناصر خارجى، بر شهروند تأثير مى گذارند. تأثير اين عناصر بر فرد منجر

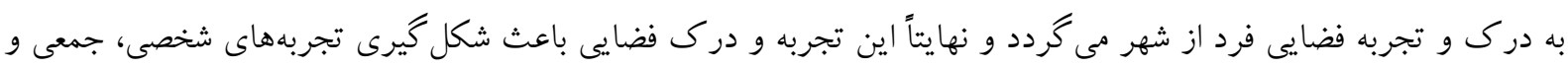

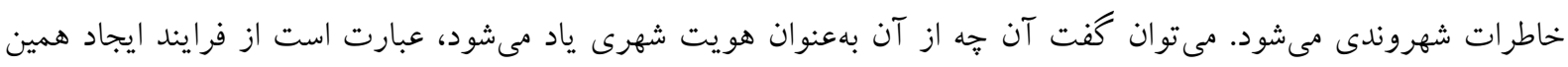
احساس ميان فرد بهعنوان اشهروند" و شهر و عناصر آن بهعنوان اعنصر خارجى" (Sabri \& Sharzadeh Mehrabi, 2006). 
هويت شهرى به اقسام مختلف تعريفشده است كه هر كدام به مفهوم تمايز اشاره دارد (Cheshmehzangi, 2015). مفاهيم مورداستفاده براى هويت شهرى شامل هويت مكان، حس مكان، تصوير مكان (Bell \& De-Shalit, 2011)، شخصيت مكان

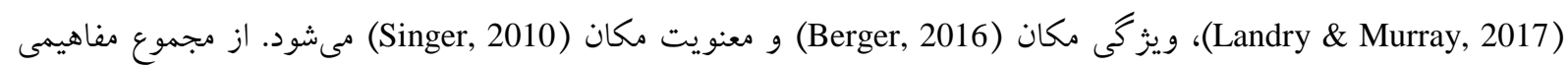
كه براى تعريف هويت شهرى استفادهده است مىتوان نتيجه گرفت كه رابطه بين مردم و مكان كه بهوسيله ابعاد عاطفى و و و

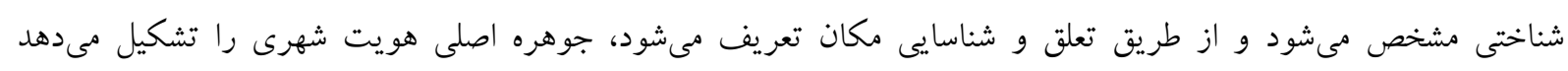

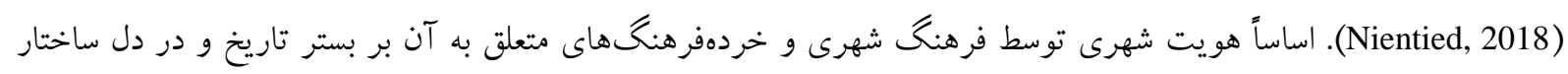

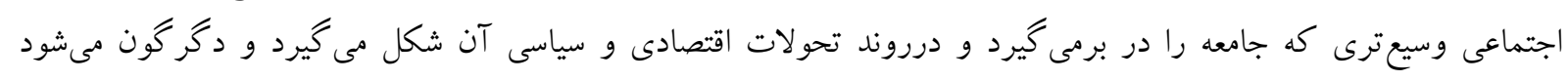

.(Piran, 2005)

ابعاد هويت فضايى و ازجمله هويت شهرى متعدد و روابط بين آنها بسيار يِيجيده است اما سه وجه كليدى كه بر اساس آن

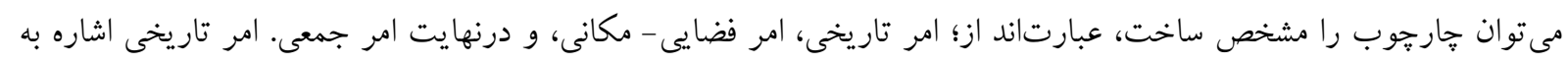

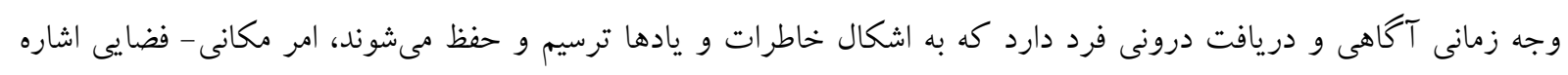

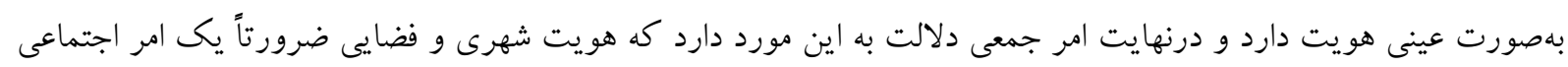

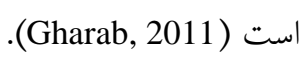

كوين لينج دو كاركرد را براى هويت شهر قايل است؛ اول اينكه به انسان قدرت تشخيص مىدهد كه بتواند شهر را بخواند

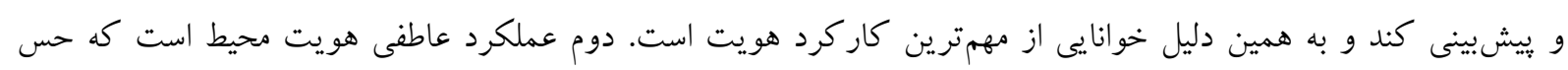

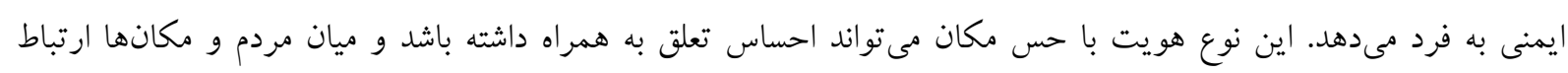
برقرار كند (Lynch, 1995).

براى بررسى هويت هر شهر مىبايد در جهت شناخت صفات اختصاصى و برجستهٔ متغيرهاى تشكيلدهنده سه دسته از

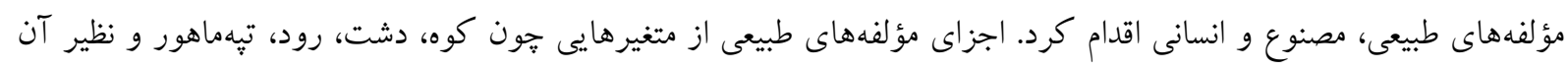

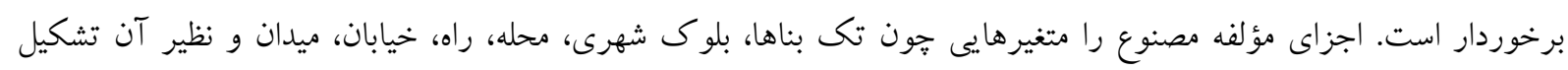

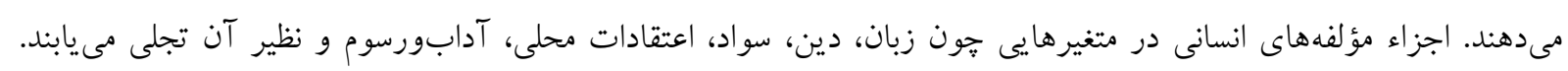

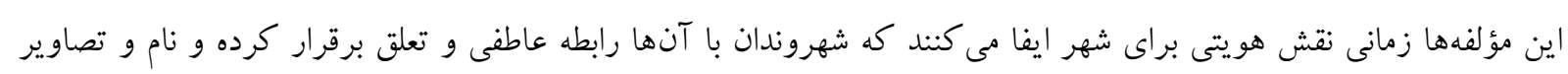

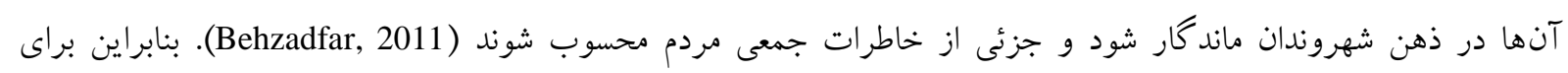

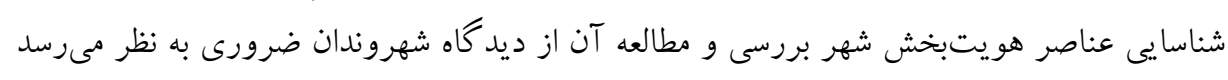

\section{جهارجوب تئوريك تحقيق}

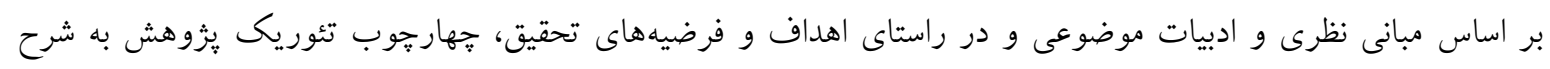

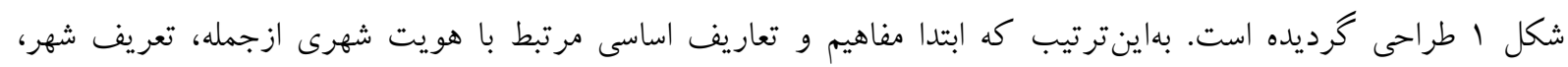

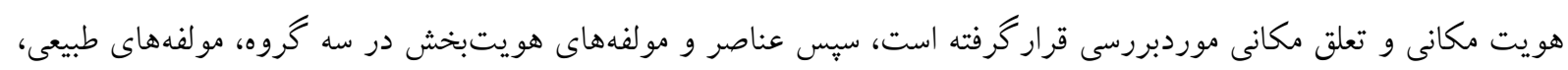

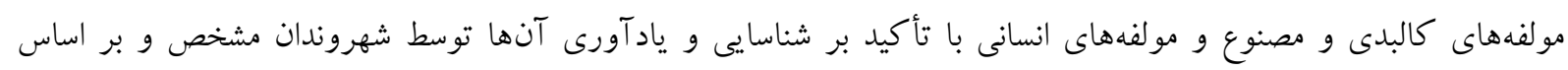

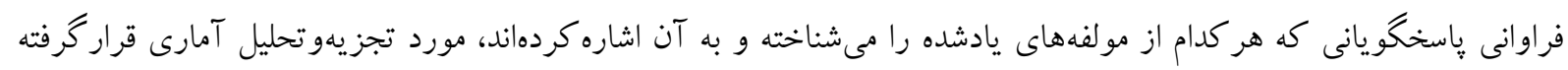




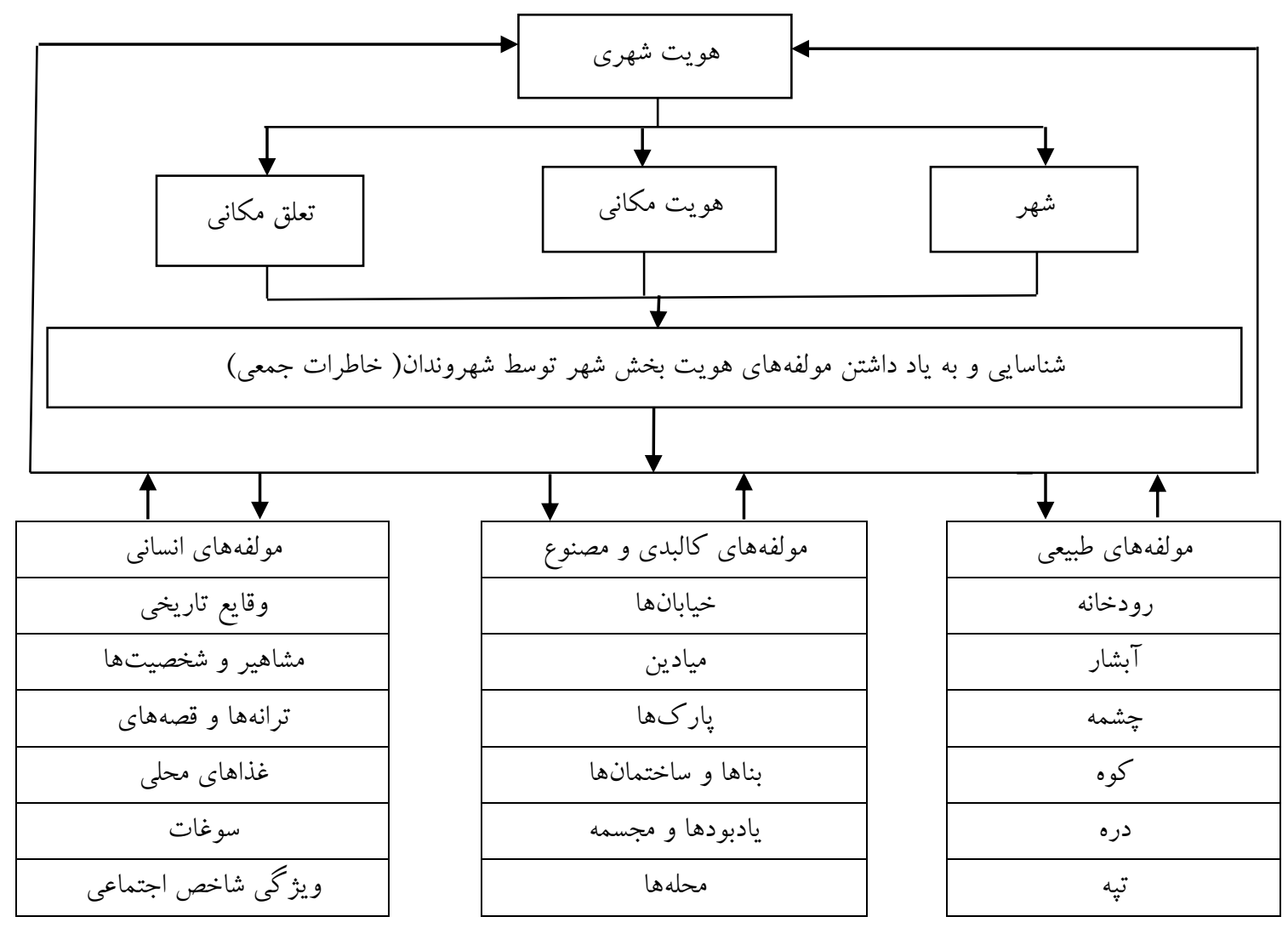

شكل 1- جهارجوب مفهومى تحقيق

روش تحقيق

اين تحقيق از نوع توصيفى - تحليلى و روش كردآورى اطلاعات به دو روش اسنادى (كتابخانهاى) و ويمايشى (يرسشنامه)

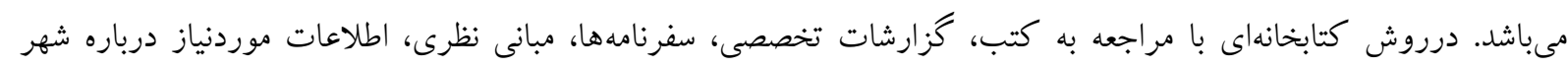

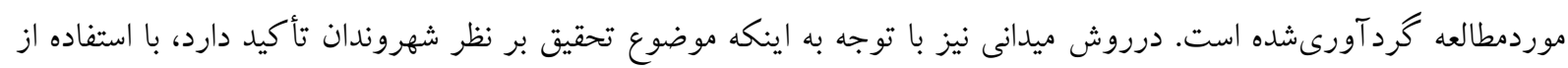

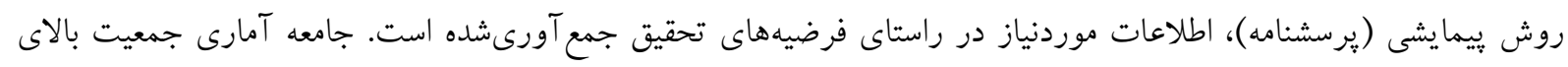

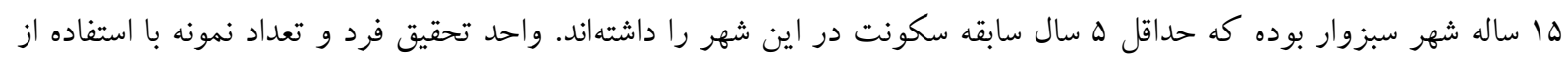

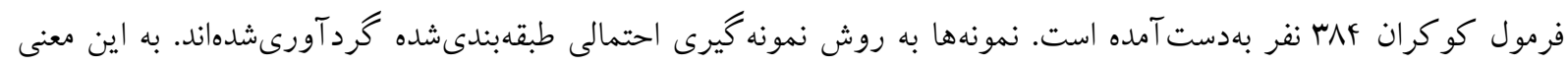

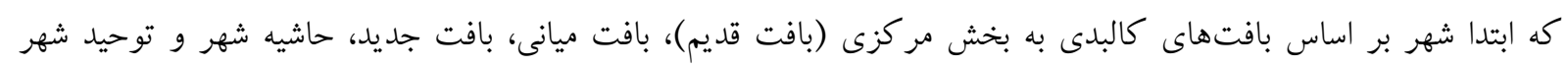

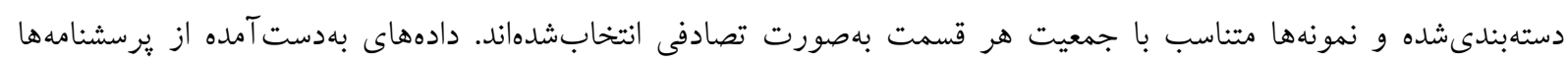

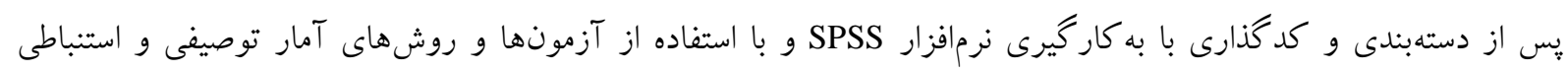
مورد تجزيهو تحليل قرار گرفتهاند.

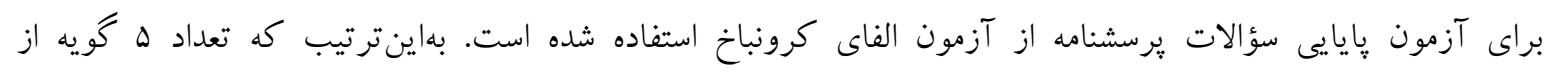

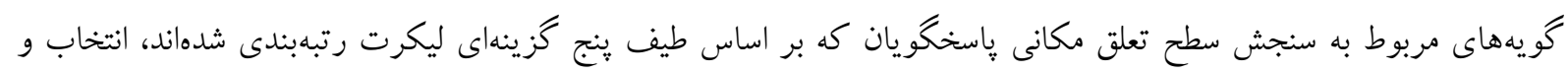

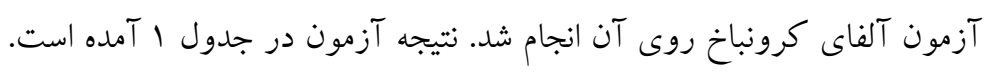


تحليلى بر عناصر هويتبخش شهر سبزوار با تأكيد بر ديدكاه شهروندان /190/

DOI: $10.29252 /$ geores.33.2.158

جدول ا - نتيجه آزمون آلفاى كرونباخ جهت سنجش بايايى باياننامه

\begin{tabular}{|c|c|c|c|c|}
\hline ضريب آلفاى كرونباخ & تعداد گويه ها & درصد معتبر & ت تعداد معتبر & تعداد دادهها \\
\hline$\cdot / 119$ & a & $\cdot / M$ & $r \Delta \Lambda$ & rAf \\
\hline
\end{tabular}

در آزمون آلفاى كرونباخ هُنان جه ضريب آلفاى كرونباخ از V/ • بيشتر باشد، بيانكر وجود پِايايى در دادههاست. با توجه

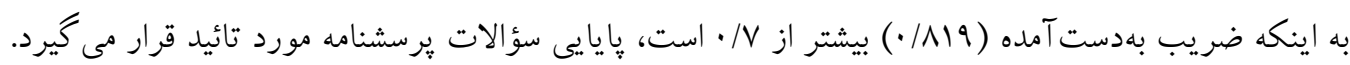

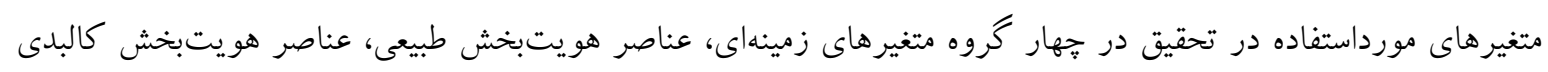

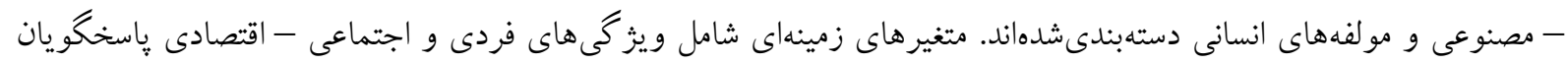

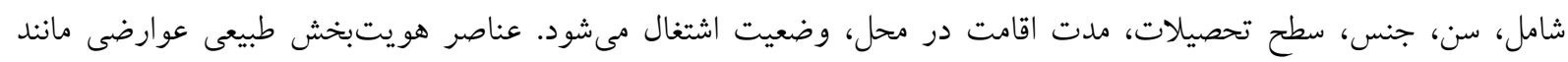

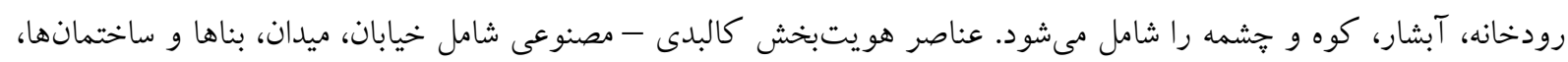

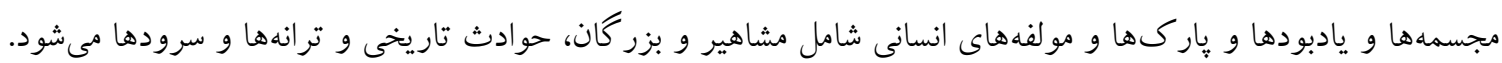

معرفى محدوده موردمطالعه

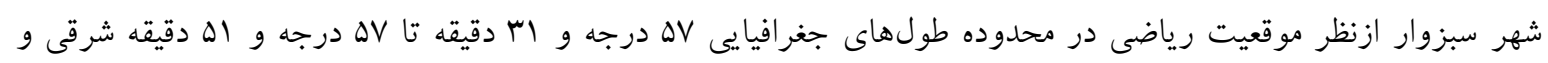

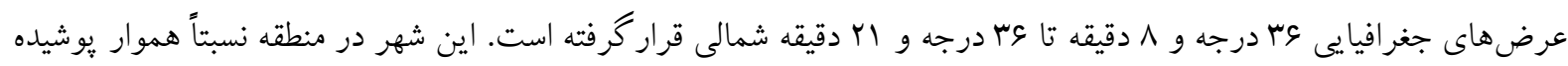
شده از رسوبات آبرفتى با ارتفاع •Vو متر از سطح دريا قرار كرفته است.

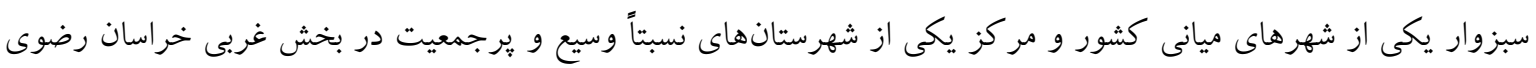

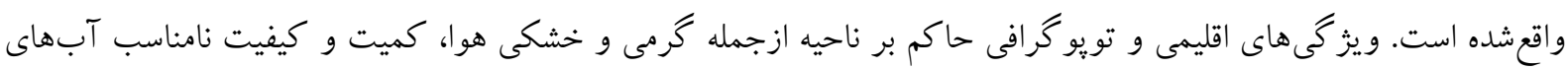

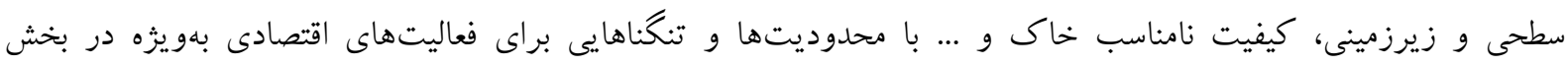

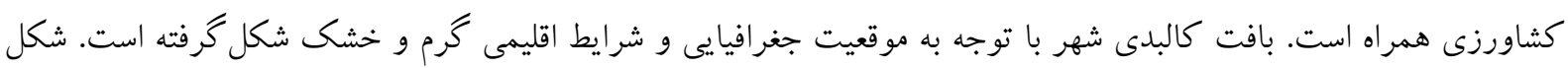

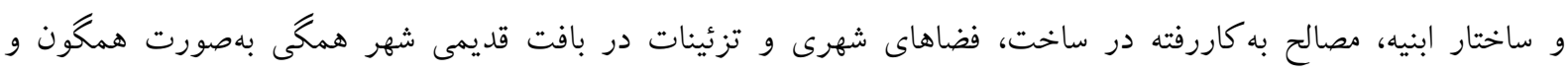

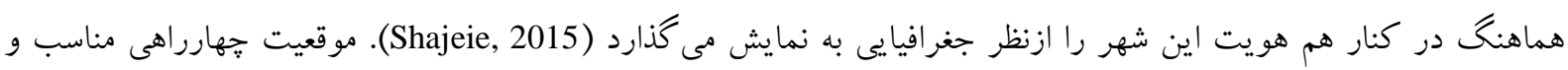

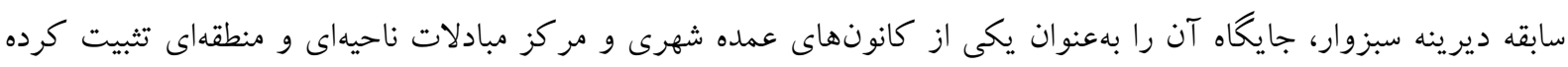

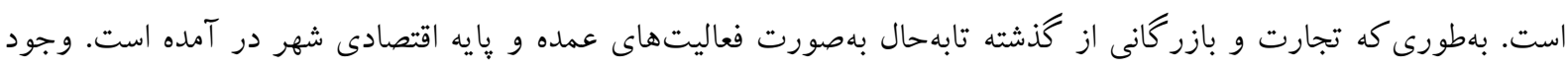

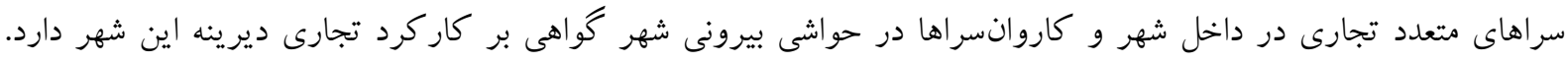

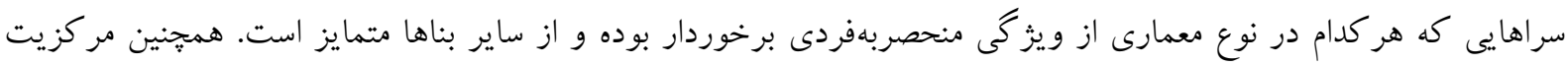

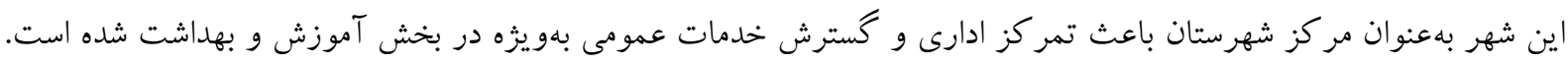

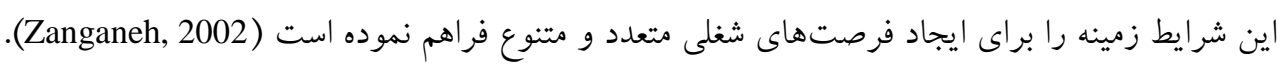

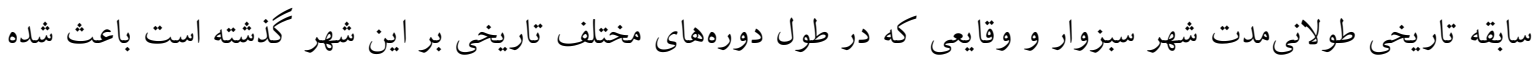

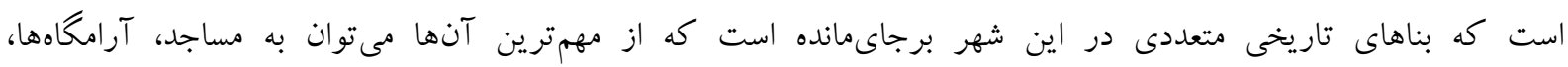

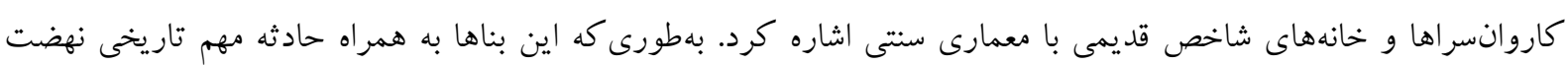

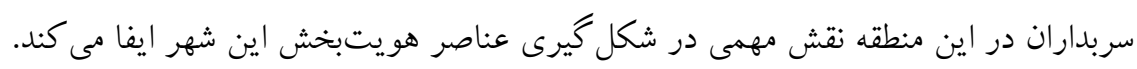

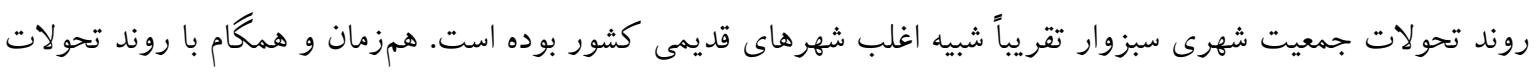

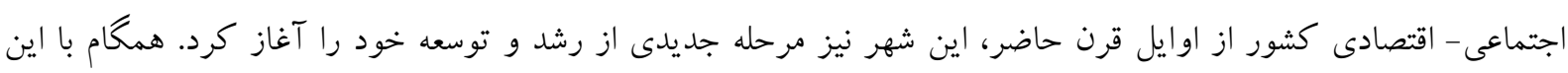




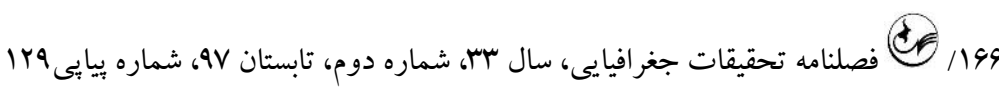

تحولات جمعيتى، توسعه فيزيكى شهر نيز با روندى متفاوت در دورههاى مختلف صورت گرفته و باعث تحول در ساخت

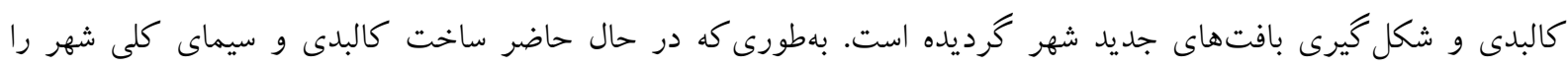
تركيبى از بافتهاى قديم و جديد (بافت جديد منظم، بافت حومهاى و نيمه روستايى نامنظم و بافت نايبوسته منظم) تشكيل

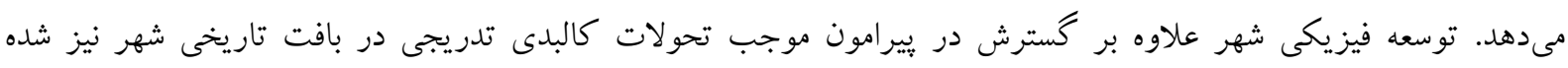

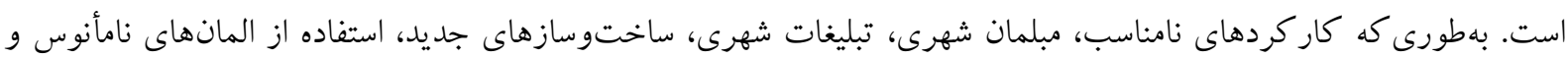
بى ربط در بافت تاريخى باعث از دست دادن عناصر هويتبخش در اين بافت شده است (Shajeie, 2015). ادامه اين روند مىتواند منجر به نابودى بيشتر عناصر هويتبخش شهرى شده و بحران هويت را در بيى داشته باشد.

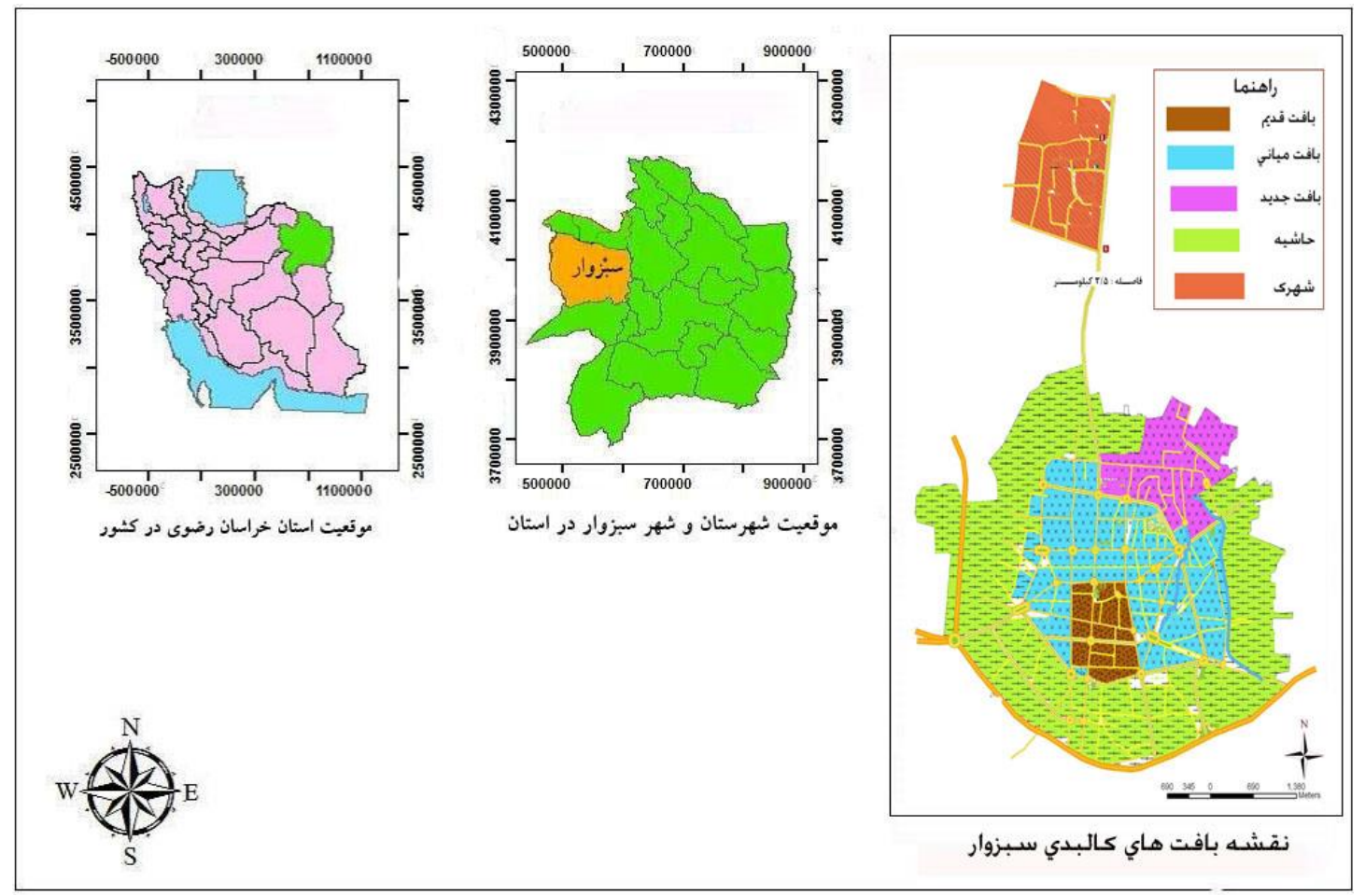

شكل r- موقعيت شهر سبزوار در استان خراسان رضوى و كشور

يافتههاى توصيفى تحقيق

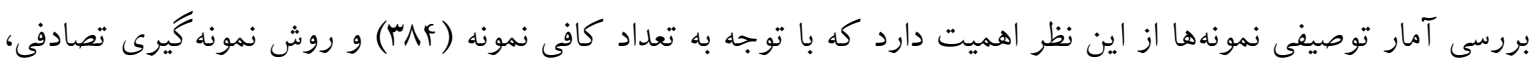

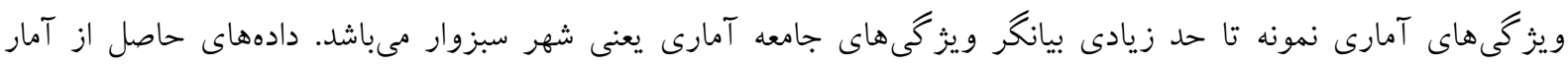

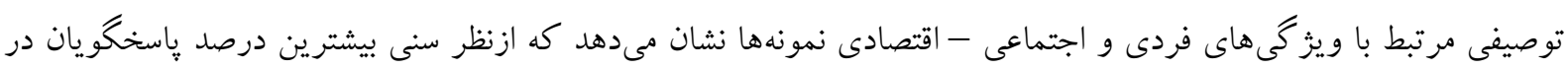

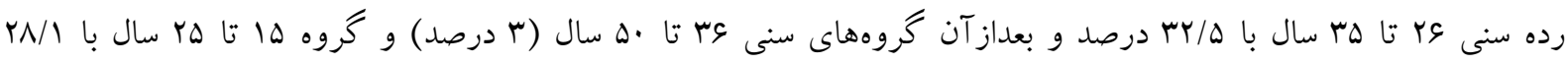

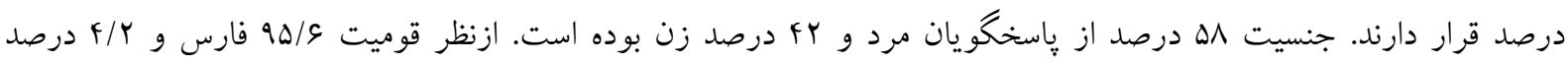

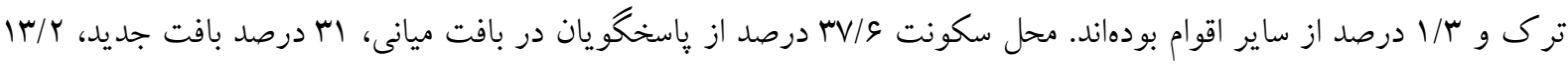

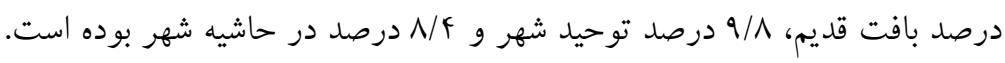

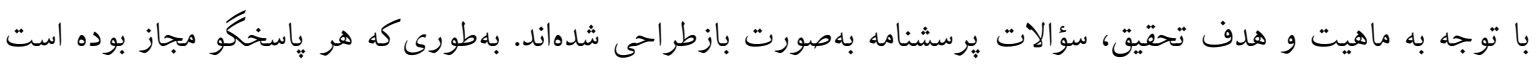

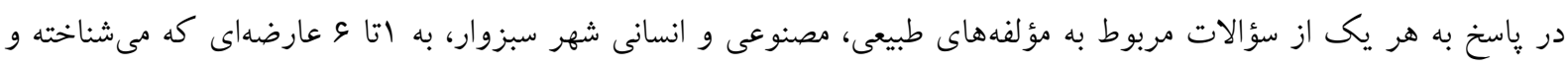

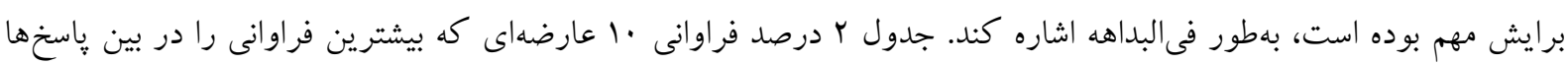


به خود اختصاص دادهاند را نشان مىدهد. عارضهاى كه بيشترين درصد رادار است نشاندهنده اين است كه افراد بيشترى آن را مىشناخته و اسم آن را ذكر كردهاند.

جدول r- درصد فراوانى عوارضى كه ياسخكويان آن را مىشناخته و به آن اشارهكردهاند'

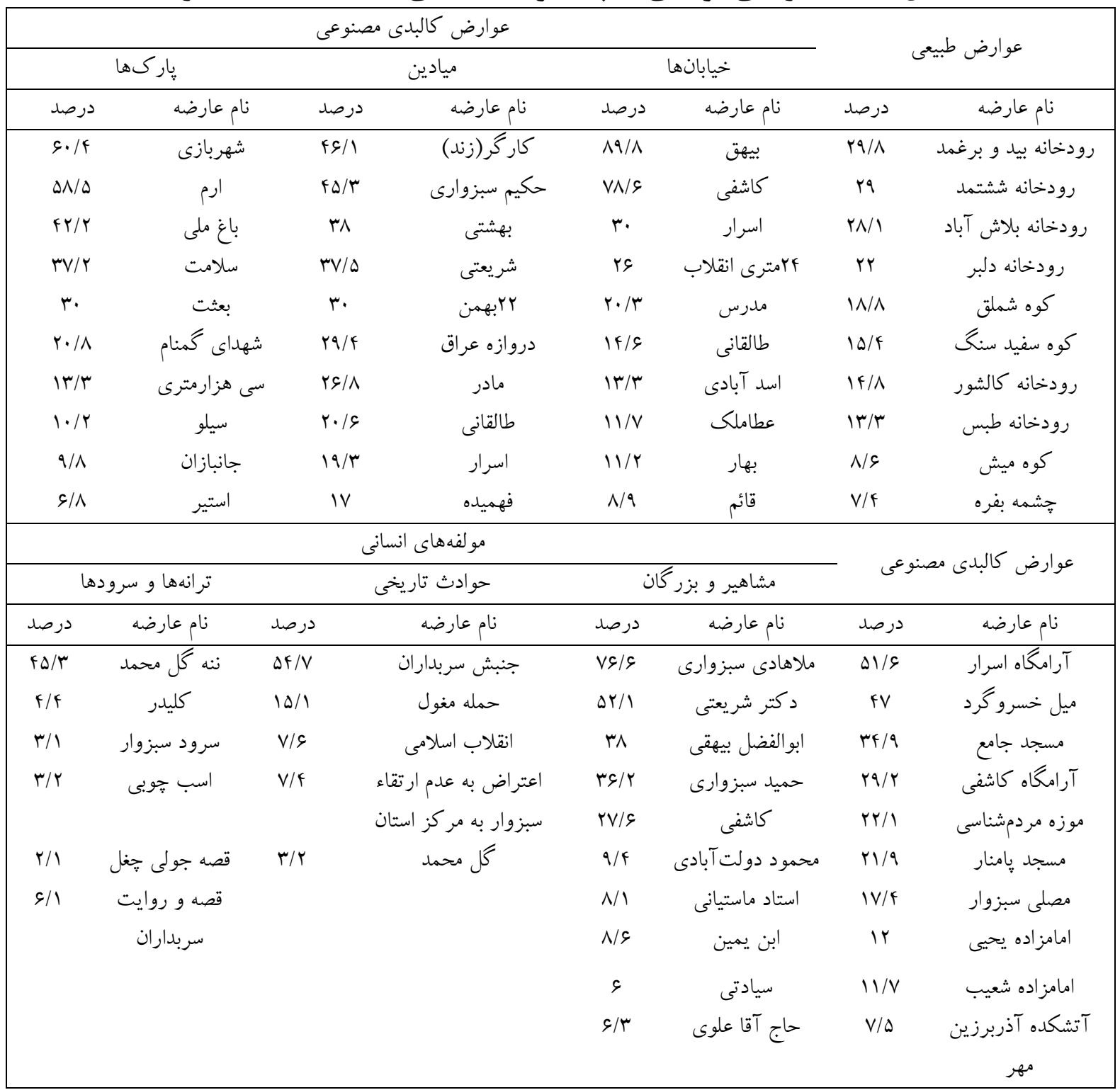

دادههاى جدول بالا نشان مىدهد كه در بين عوارض طبيعى، رودخانههاى بيد و برغمد، ششتمد و بلاش آباد شناختهشدهترين

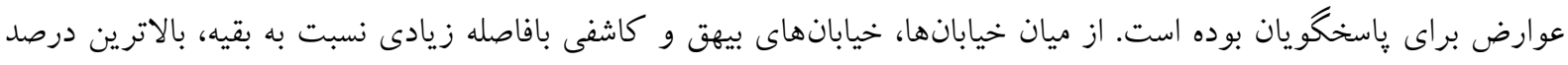

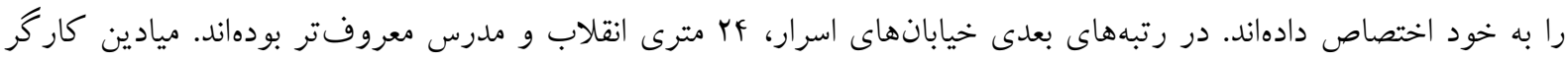

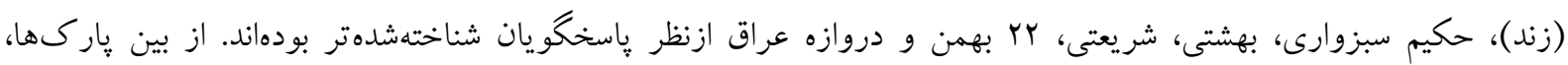

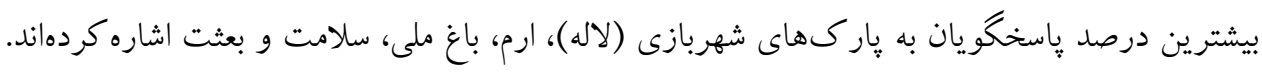

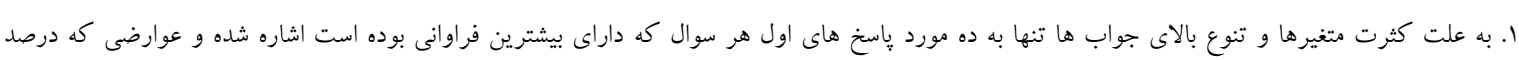

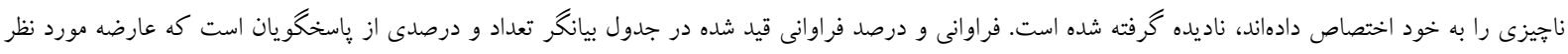

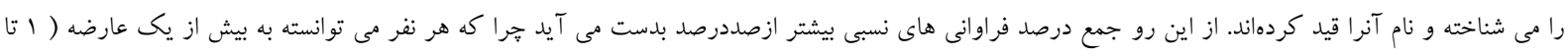




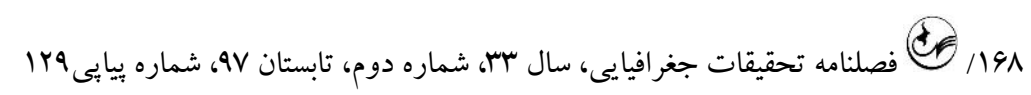
از بناهاى تاريخى معروف ازنظر ياسخگويان مىتوان به آرامگاه اسرار، ميل خسروجرد، مسجد جامع و آرامكاه كاشفى اشاره

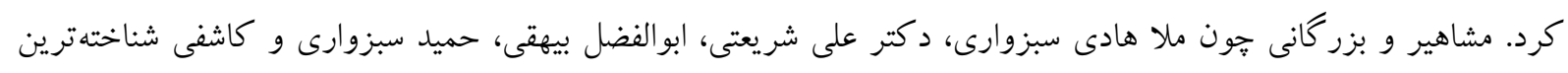

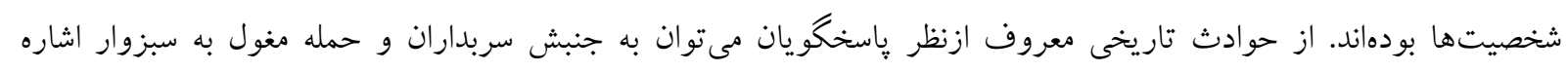

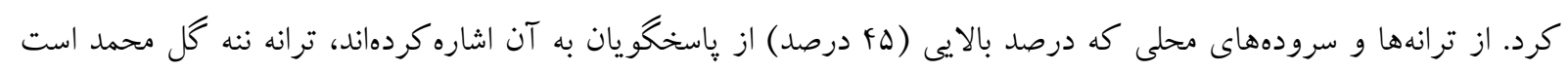

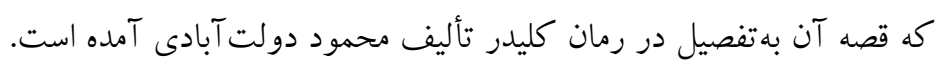

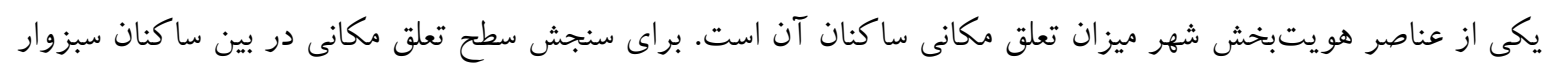

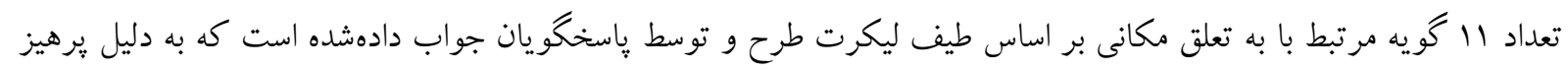

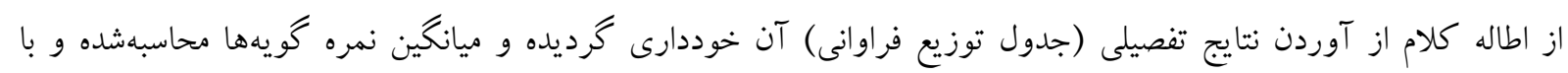

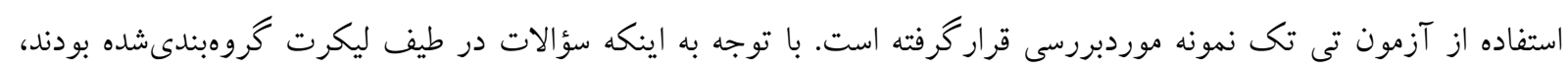

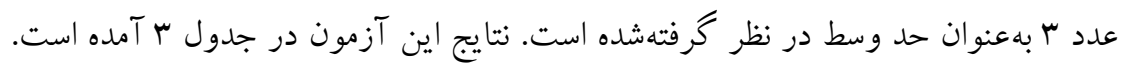

جدول r- نتايج آزمون تى تست تك نمونه براى ميانكين محاسبهشده از 11 كويه مربوط تعلق مكانى

\begin{tabular}{|ccccc|}
\hline ميانكين تعلق مكانى & مؤلفه \\
\hline
\end{tabular}

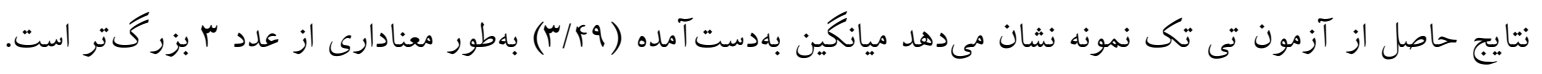

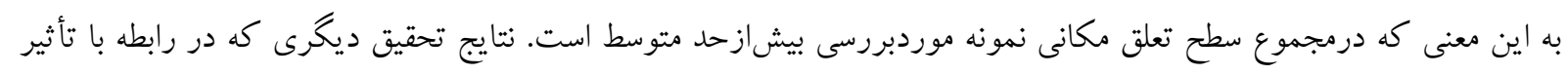

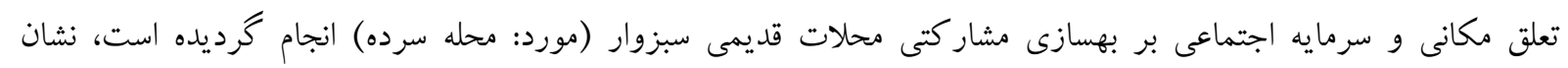

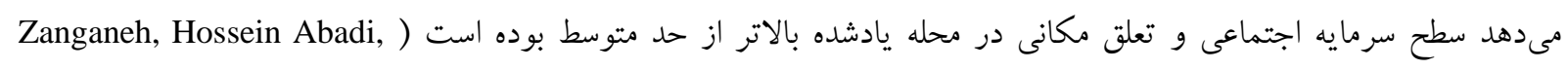

.(Roshandel, \& Nabipoor, 2014

\section{يافتههاى تحليلى}

يكى از سؤالهاى اساسى اين يزوهش اين است كه ازنظر شهروندان كدام دسته از عناصر طبيعى، مصنوعى و انسانى نقش

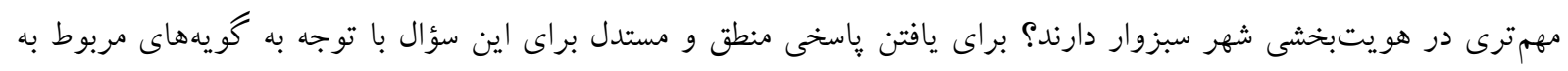

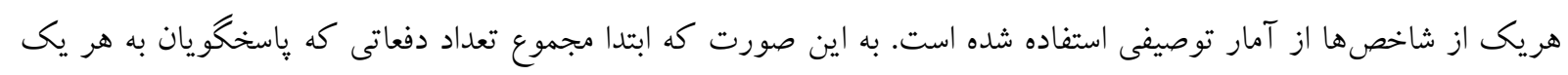

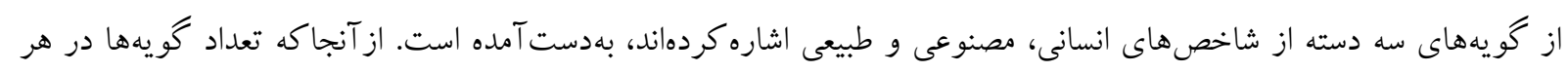

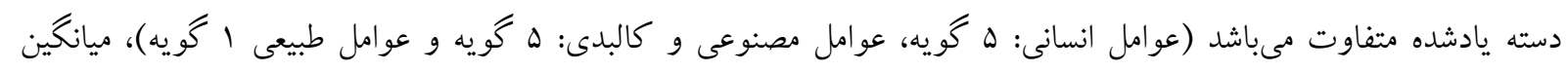

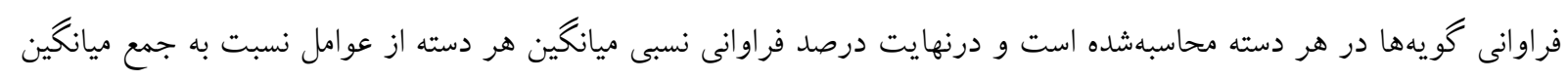

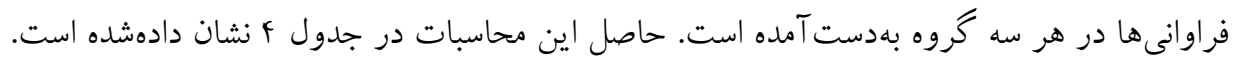


تحليلى بر عناصر هويتبخش شهر سبزوار با تأكيد بر ديدكاه شهروندان /199

جدول ع- مجموع، ميانكين و درصد فراوانى نسبى مؤلفه ها به تفكيك سه كروه

\begin{tabular}{|c|c|c|c|c|c|}
\hline \multicolumn{2}{|c|}{ مولفه هاى طبيعى } & \multicolumn{2}{|c|}{ 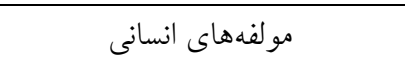 } & \multicolumn{2}{|c|}{ مولفههاى مصنوعى و كالبدى } \\
\hline جمع فراوانىها & ن نام عارضه & 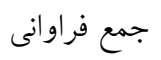 & 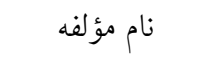 & جمع فراوانى & 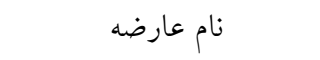 \\
\hline \multirow{6}{*}{$v \cdot v$} & \multirow{6}{*}{ كوه رو دوانه، آبشار، } & MYF & واقعه تاريخى & IIVD & خيابان \\
\hline & & $1 \cdot 10$ & مشاهير و بزر كان & 119. & ميدان \\
\hline & & THE & ترانه و قصه & $11 \cdot 0$ & يارك \\
\hline & & $\Lambda \cdot v$ & غذاى محلى & 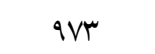 & بناى تاريخى \\
\hline & & s.r & سوغات سبزوار & F9V & محله قديمى \\
\hline & & - & - & ITAF & مسجد و امامزاده \\
\hline$v \cdot v$ & & rqVa & - & s19f & جمع \\
\hline$V \cdot V$ & & $\Delta 90$ & - & $1 . r 4$ & ميانگين در هر گروه \\
\hline$r \cdot / r q$ & & $r \Delta / F q$ & - & $F F / Y I$ & درصد فراوانى نسبى در كل \\
\hline
\end{tabular}

دادههاى جدول بالا نشان مى دهد كه درصد فراوانى نسبى به ترتيب در گروه مولفههاى مصنوعى و كالبدى ( (آFF/ درصد)،

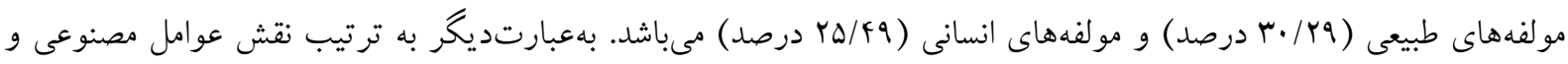

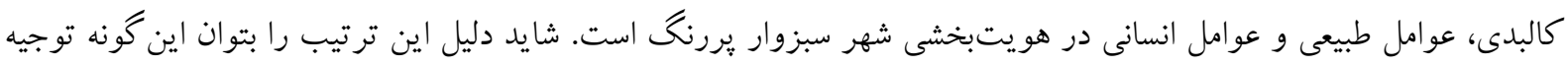

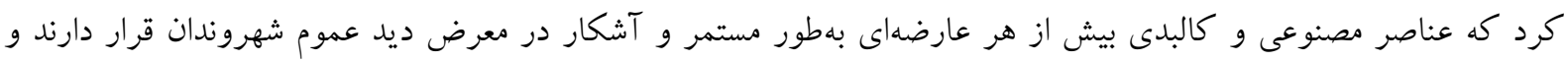

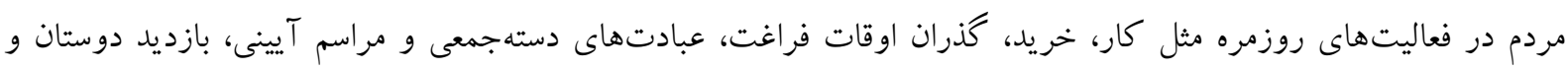

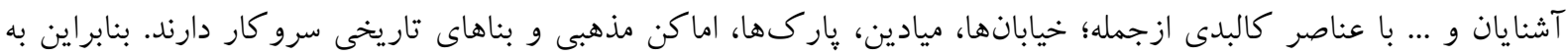

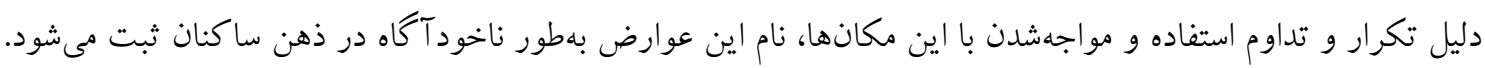

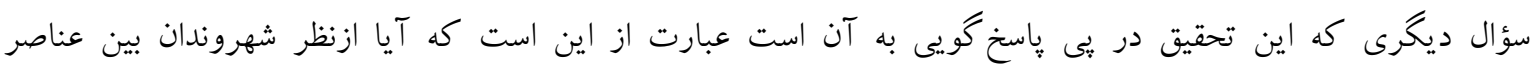

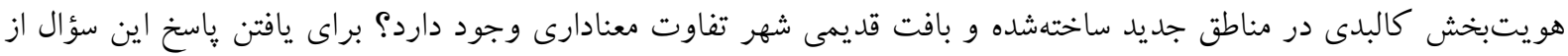

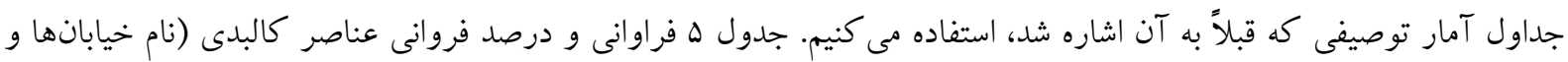
ميادين) را كه توسط ياسخكو يان به آن اشارهشده است، نشان مى إدهد.

جدوله - توزيع و درصد فروانى عناصر كالبدى( نام خيابانها و ميادين و پار ككها)

\begin{tabular}{|c|c|c|c|c|c|}
\hline درصد فراوانى & نام يارك & درصد فراوانى & نام ميدان & درصد فراوانى & نام خيابان \\
\hline$s \cdot / f$ & شهربازى & $F s / 1$ & كارگر(زند) & $\wedge 9 / \wedge$ & بيهت \\
\hline$\Delta \Lambda / \Delta$ & ارم & $F \Delta / \mu$ & حكيم سبزوارى & $V \Lambda / s$ & كاشفى \\
\hline$F Y / Y$ & باغ ملى & $\mu$ & بهشتى & r. & اسرار \\
\hline$r V / r$ & سلامت & $r V / \Delta$ & شريعتى & rE & Frابترى انقلاب \\
\hline$r$. & بعثت & $r$. & Y Yبهمن & $r \cdot / r$ & مدرس \\
\hline$r \cdot / \Lambda$ & شهداى گمنام & $r q / F$ & دروازه عراق & $\mid f / s$ & طالقانى \\
\hline $1 \mu / \mu$ & سى هزارمترى & $r \varepsilon / \Lambda$ & مادر & $1 \% / r$ & اسد آبادى \\
\hline $1 \cdot / r$ & سيلو & $r \cdot / s$ & طالقانى & $11 / \mathrm{V}$ & عطاملك \\
\hline $9 / \wedge$ & جانبازان & $19 / \mu$ & اسرار & $11 / r$ & بهار \\
\hline$\Lambda / \varepsilon$ & استير & IV & شهيد فهميده & $1 \cdot / 4$ & شريعتمدارى \\
\hline
\end{tabular}


. TV. دادههاى جدول بالا نشان مىدهد كه از ميان ·r عنصر كالبدى شامل خيابانها، ميادين و واركهاى نامبرده شده توسط

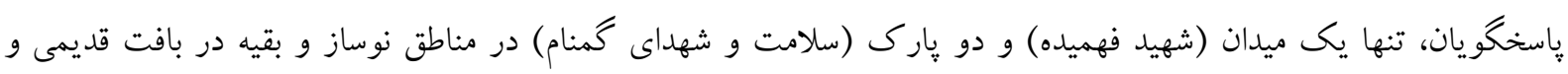

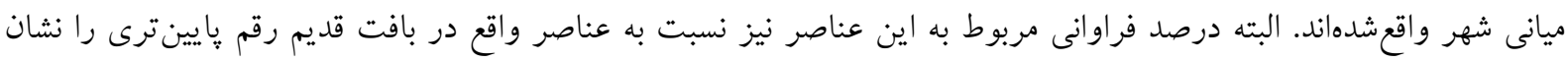

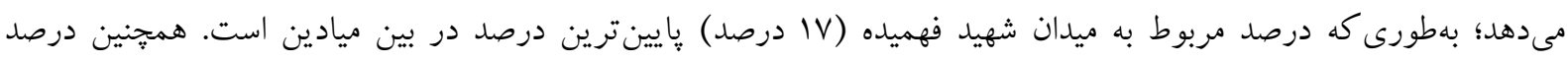

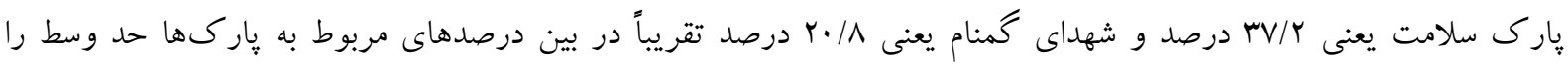

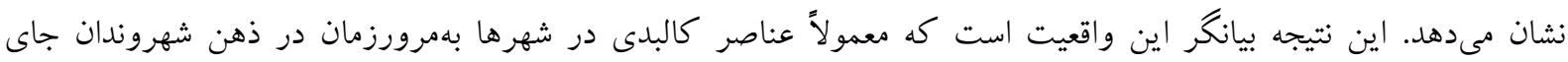

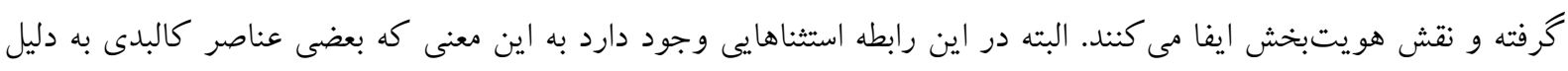

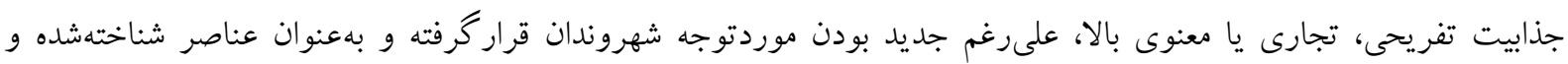

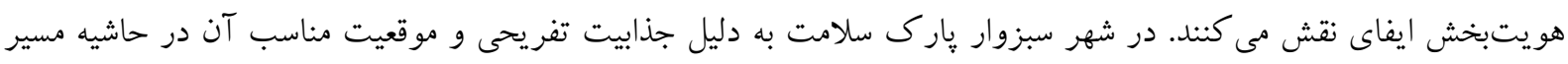

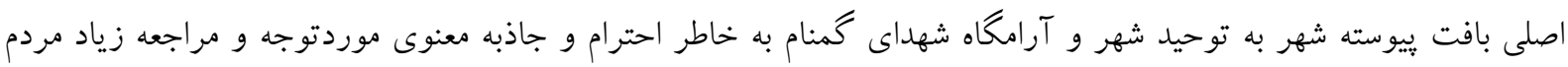

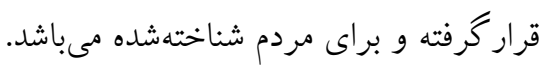

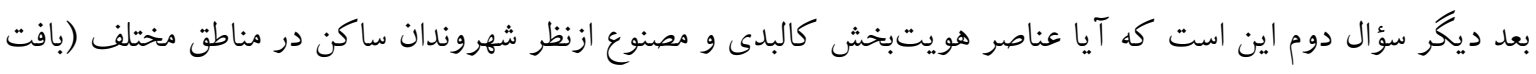

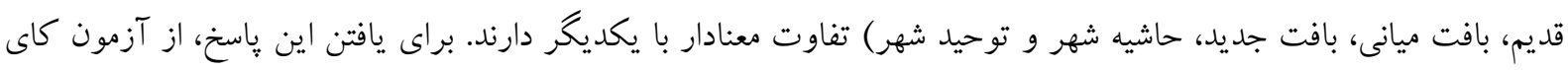

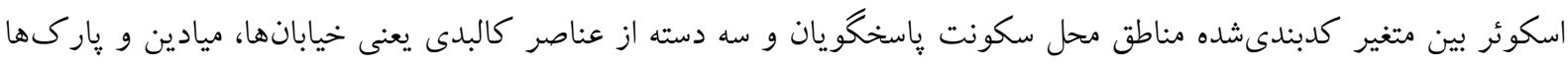

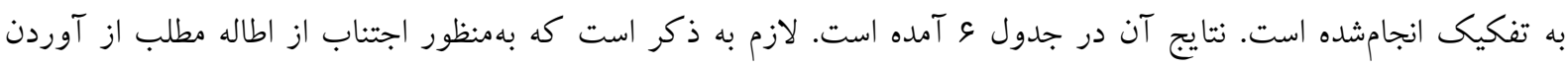

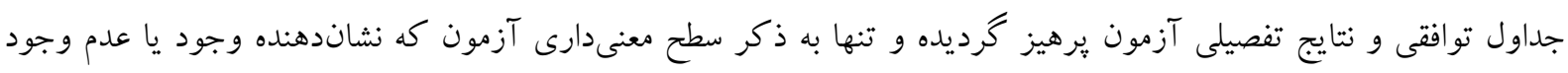
رابطه بين دو متغير يادشده است، بسنده شده است.

\section{جدول - - نتايج آزمون كاى سكوئر بين متغير محل سكونت پاسخغويان و مولفه هاى كالبدى و مصنوع}

\begin{tabular}{|c|c|c|c|c|c|}
\hline سطح معنادارى & (يار كؤها) & سطح معنادارى & مؤلفه & سطح معنادارى & (خيابانها) \\
\hline ./gFr & باغ ملى & . /VIF & كارگر (زند) & $\cdot / T M A$ & بيهق \\
\hline.$/ Q Y V$ & شهربازى & ./AIr & حكيم سبزوارى & $\cdot / \cdot \Lambda r$ & كاشفى \\
\hline$\cdot / V V F$ & لاله & $\cdot / \pi / 9$ & سى هزارمترى & $\cdot / 1 \cdot r$ & مدرس \\
\hline . /945 & ارم & $\cdot / F I f$ & دروازه عراق & / TAD & طالقانى \\
\hline$\cdot|V S|$ & سلامت &.$/ 1 S V$ & شريعتى & . / 1 rq & شر يعتمدارى \\
\hline$\cdot / \cdot v \varepsilon$ & بعثت &.$/ 419$ & فهميده & $\cdot / T \wedge \Delta$ & طالقانى \\
\hline
\end{tabular}

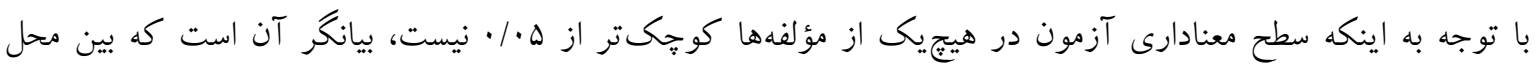

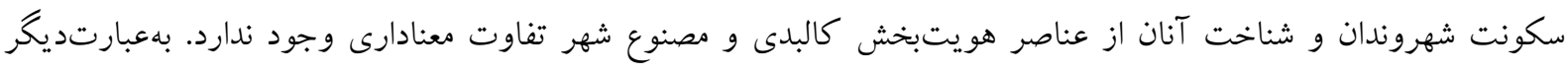

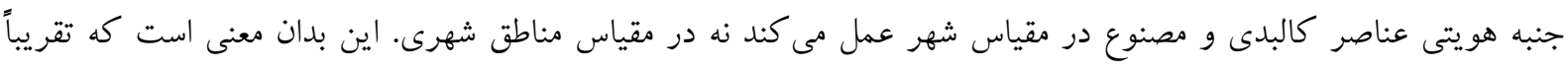

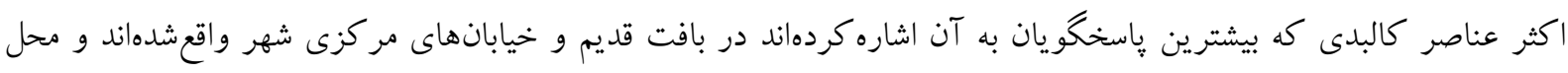

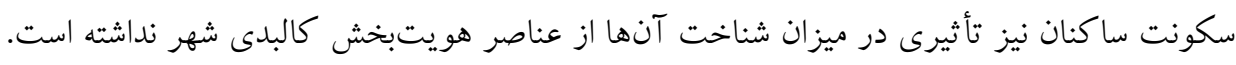


عناصر طبيعى، كالبدى و مصنوعى و مولفه هاى فرهنكى و اجتماعى سه عنصر اصلى هويتبخش شهرها هستند كه شرايط و

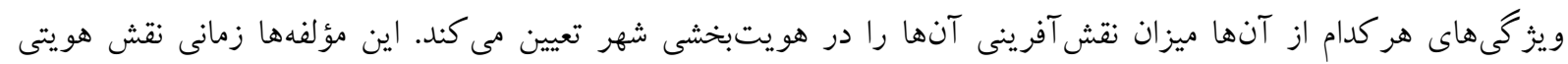

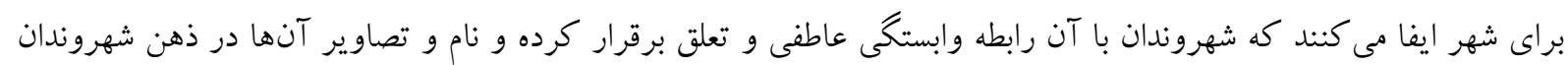

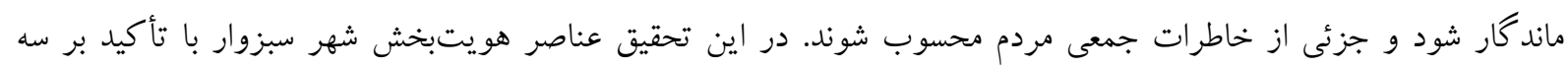

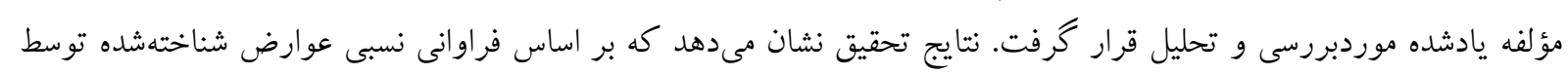

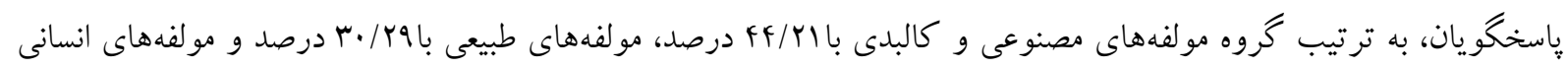

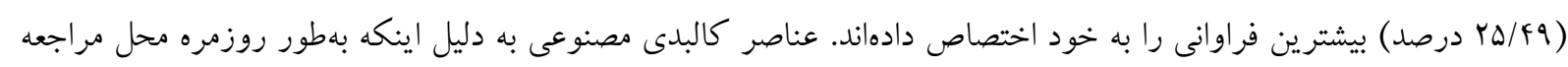

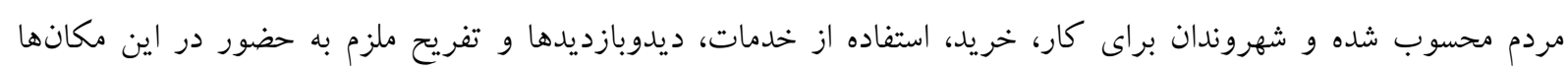

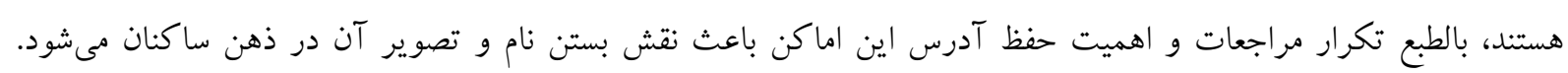

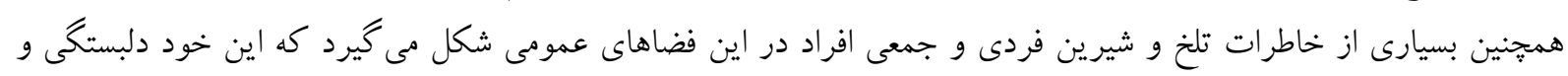

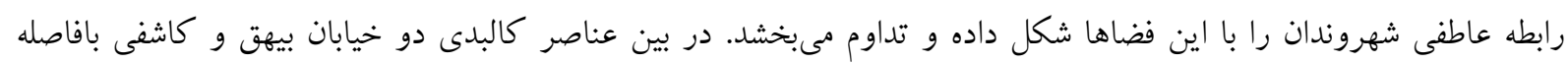

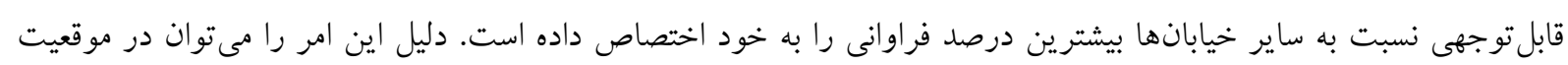

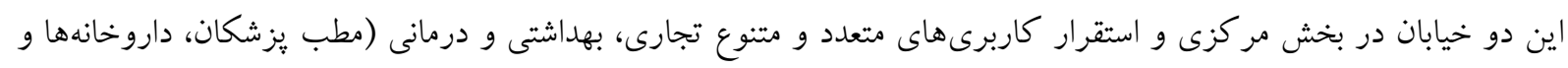

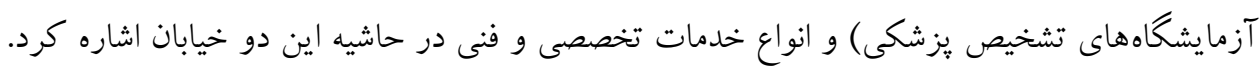

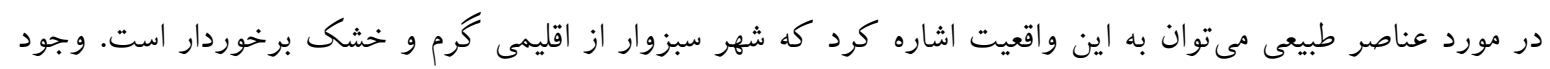

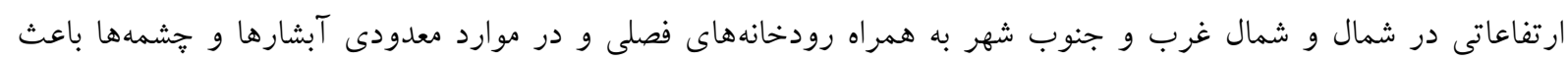

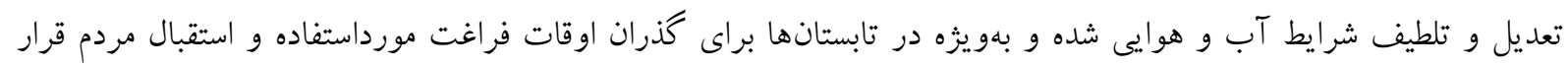

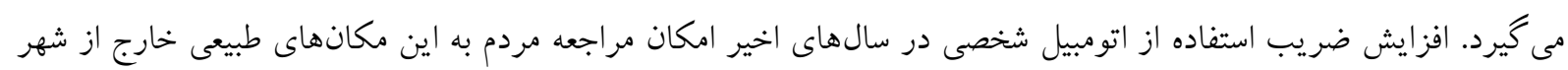

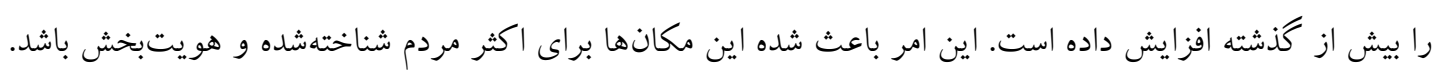

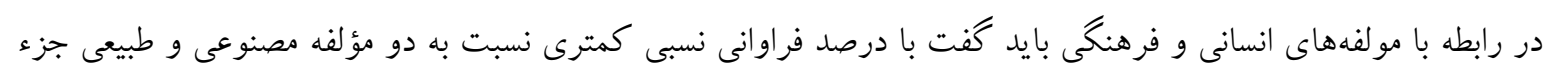

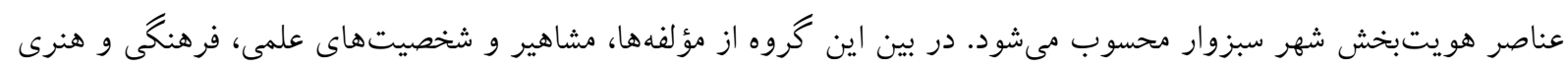

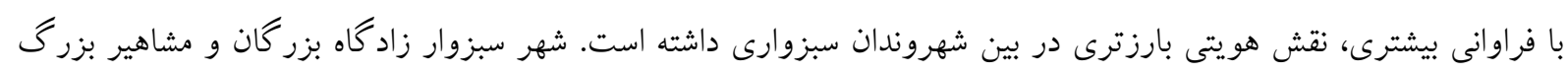

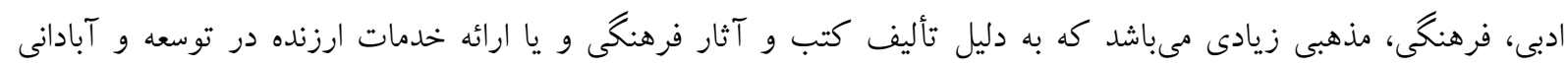

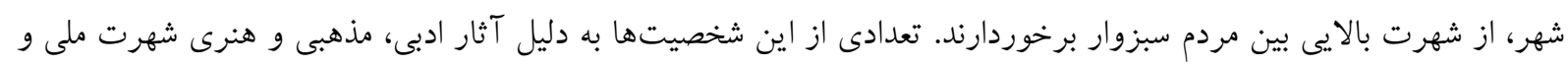

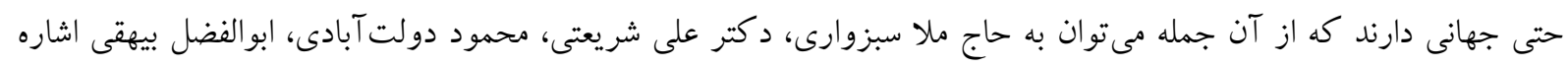

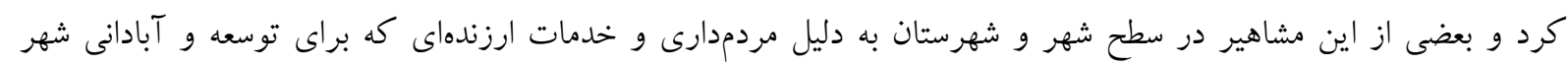
انجام دادهاند در بين مردم به نيكنامى شناخته إندهاند.

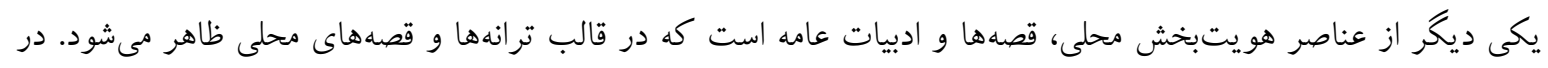

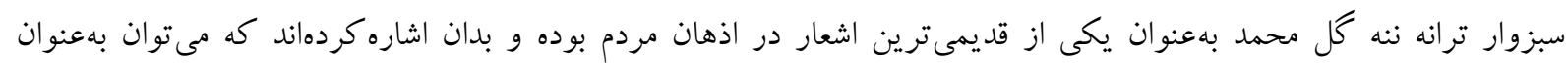

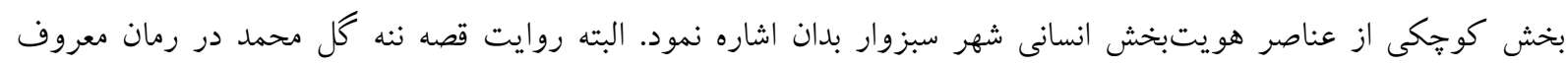
كليدر باعث شهرت و ماند كارى اين قصه در اذهان شده است. 


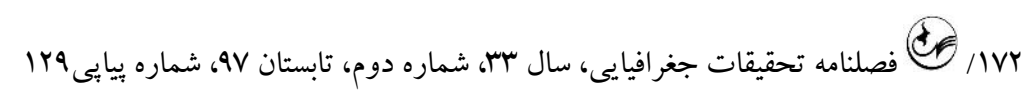
از ديكر نتايج اين يزوهش اين بود كه از ميان ·r عنصر كالبدى شامل خيابانها، ميادين و پار كىهاى نامبرده شده توسط

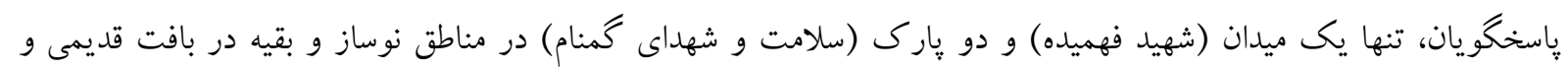

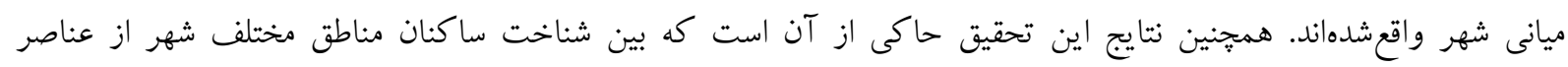

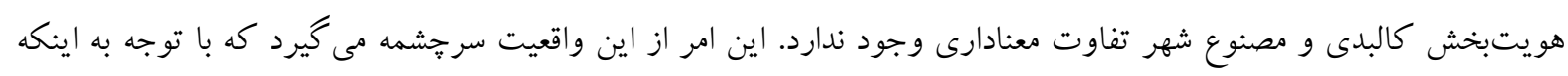

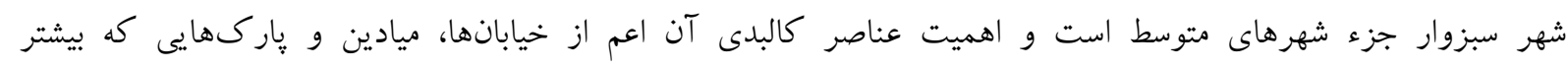

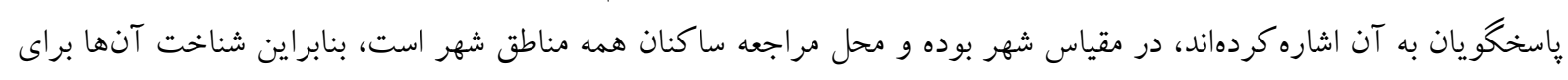
ساكنان مناطق مختلف تفاوت معنادارى نشان نمىدهد.

بيشنهادات

ازآنجاكه هويت شهر يكى از معيارهاى توسعه و شاخص مهمى در ارتقاء كيفيت زندكى فردى و اجتماعى و منبع نشاط و

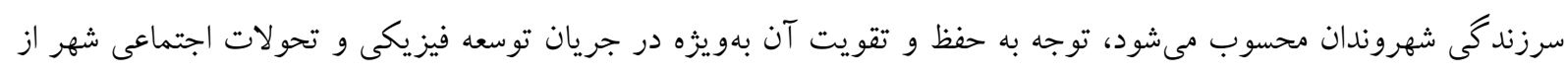

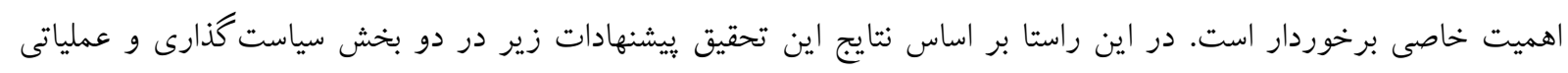
مطرح مى گردد:

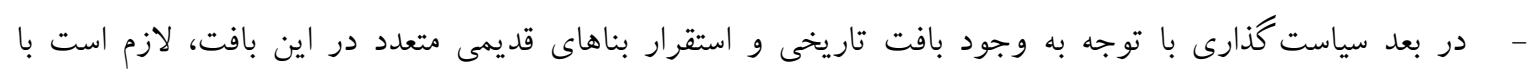

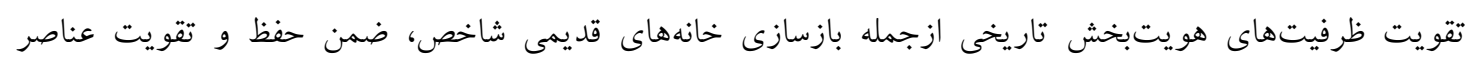

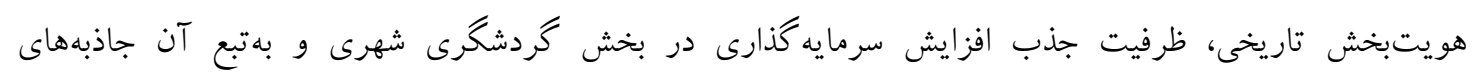

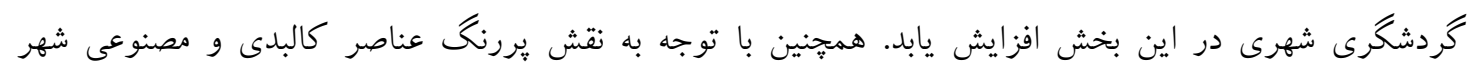

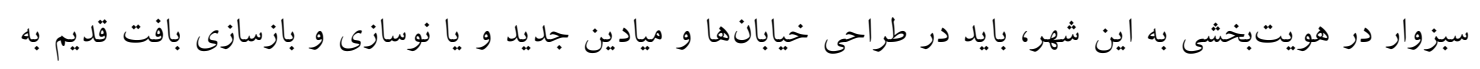

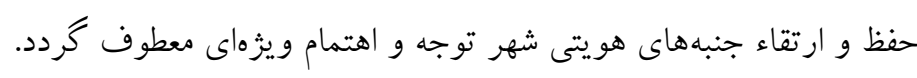

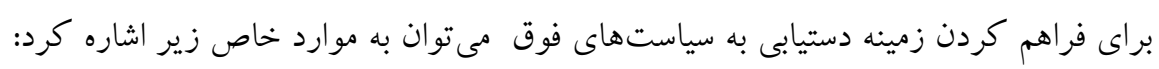

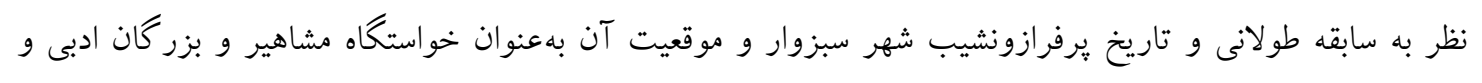

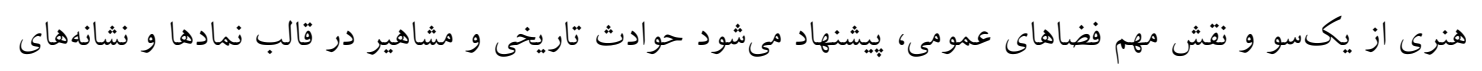

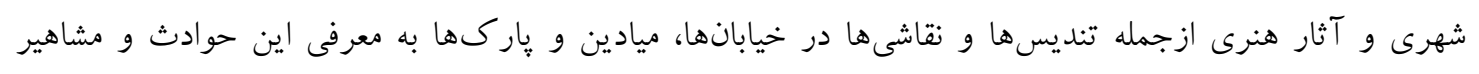
ير برداخته شود.

براى معرفى و يادبود شخصيتهاى علمى و فرهنكى ازجمله ابوالفضل بيهقى و حكيم سبزوارى و يا رويدادهاى

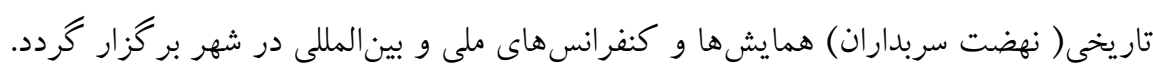

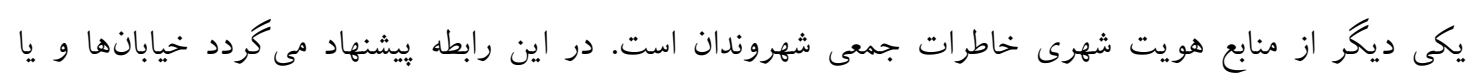

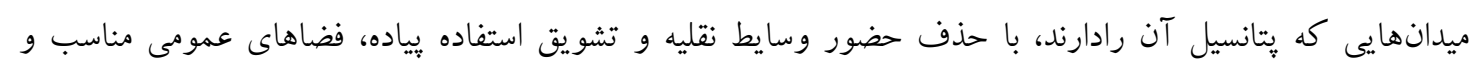

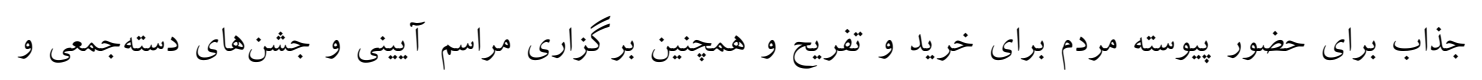
نمايش هاى خيابانى ايجاد شود.

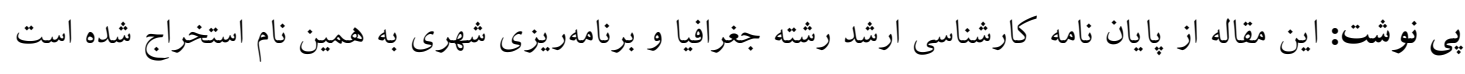
كه در دانشگاه حكيم سبزوارى دفاع شده است. 


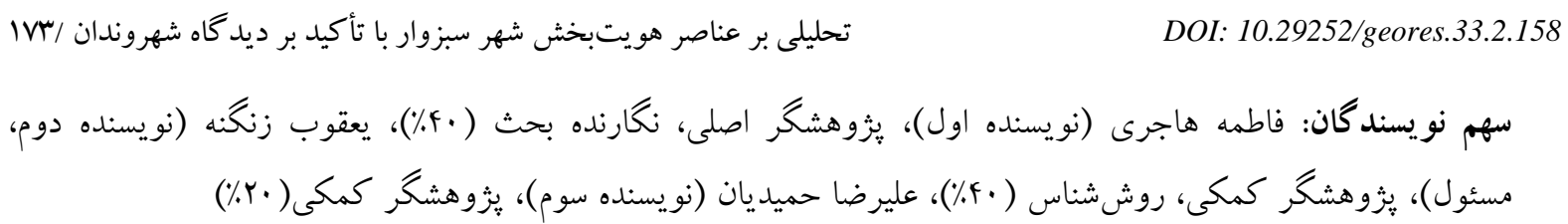

منابع و مآخذ

Alikhani, A. A. (2007). Identity and identity crisis (Second ed.). Tehran: Jahad University Press. (Persian)

Barreto, M., \& Ellemers, N. (2000). You can't always do what you want: Social identity and self-presentational determinants of the choice to work for a low-status group. Personality and Social Psychology Bulletin, 26(8), 891-906. [DOI:10.1177/01461672002610001]

Behzadfar, M. (2011). The identity of city; A look at the identity of Tehran (Third ed.). Tehran: City Publishing. (Persian)

Bell, D. A., \& De-Shalit, A. (2011). The Spirit of Cities, Why the Identity of a City Matters in a Global Age. Pinceton: Princeton University Press.

Berger, T. (2016). Place, Imaginary, Identity: Place Ethnography in Truth or Consequences. (PhD Thesis), The University of New Mexico, Albuquerque.

Brocato, E. D. (2006). Place attachment: An investigation of environments and outcomes in a service context. (Doctor of Philosophy), University of Texas at Arlington.

Cheshmehzangi, A. (2015). Urban identity as a global phenomenon: hybridity and contextualization of urban identities in the social environment. Journal of Human Behavior in the Social Environment, 25(5), 391406.

Gharab, N. (2011). Urban identity. Tehran: Rahdan, Ministry of Interior, Center of Urban Planning Studies. (Persian)

Ghasemi Esfahani, P. (2004). Where are we from, identity to residential buildings. Tehran: Raozaneh. (Persian)

Habib, F., Naderi, S. M., \& Froozangohar, H. (2008). Subordinate questioning in urban discourse and identity (city phisic is subordinate identity or identity is subordinate city phisic?). City Identity, 2(3), 13-23. (Persian)

Hayati, A. (2010). Evaluation of identity components of urban neighborhoods in Evin district of Tehran. (Master's Thesis), Tarbiat Modarres University, Tehran. (Persian)

Landry, C., \& Murray, C. (2017). Psychology \& the City: The Hidden Dimension. Gloucestershire: Comedia.

Lewicka, M. (2008). Place attachment, place identity, and place memory: Restoring the forgotten city past. Journal of environmental psychology, 28(3), 209-231. [DOI:10.1016/j.jenvp.2008.02.001]

Lynch, K. (1995). City view (M. Mazini, Trans.). Tehran: Tehran University. (Persian)

Manzo, L. C., \& Perkins, D. D. (2006). Finding common ground: The importance of place attachment to community participation and planning. Journal of planning literature, 20(4), 335350. [DOI:10.1177/0885412205286160]

Murzyn-Kupisz, M., \& Gwosdz, K. (2011). The changing identity of the Central European city: The case of Katowice. Journal of Historical Geography, 37(1), 113-126. [DOI:10.1016/j.jhg.2010.04.001]

Nientied, P. (2018). Hybrid urban identity-the case of Rotterdam. Current Urban Studies, 6(1), 152173. [DOI:10.4236/cus.2018.61008]

Nofel, S. A., Kalbadi, P., \& Porjafar, M. R. (2009). Investigation and evaluation of effective indicators in urban identity (case study of Jolfa neighborhood in Isfahan city). Utophaneshahr, 2(3), 57-69. (Persian)

Noqrekar, A., Hamzehnegad, M., \& Ranjbar Kermani, A. M. (2009). An Introduction to Islamic Identity in Architecture and Urbanism. Tehran: Payame Noor University. (Persian)

Payton, M. A. (2003). Influence of place attachment and social capital on civic action: A study at Sherburne National Wildlife Refuge. (master's thesis), University of Minnesota.

Piran, P. (2005). The identity of cities; A great melee for a complex concept. Magazine Abadi, 15(48), 6. (Persian)

Qaraee, F. (2008). A comparison of the viewpoint of public and environmental designers on urban identity and its strengthening (case study: Shemiran area, north of Tehran). Architectural and Urban Planning, 1(1), 25-36. (Persian)

Rezazadeh, R. (2010). The Role and Function of Urban Identity in Promoting Citizens Identity and Their Presence in Urban Space. Shams Magazine, 8(71), 42-52. (Persian)

Riza, M., Doratli, N., \& Fasli, M. (2012). City branding and identity. Procedia-Social and Behavioral Sciences, 35, 293-300. [DOI:10.1016/j.sbspro.2012.02.091]

Sabri, S., \& Sharzadeh Mehrabi, Z. (2006). The Position of the Concept of Identity in New Towns. Paper presented at the International Conference on New Towns, Tehran. (Persian)

Sajjadzadeh, H. (2013). The role of attachment to place in the identity of urban areas (case study: Hamedan Tomb square). Bagh-Nazar Magazine, 10(25), 69-78. (Persian) 


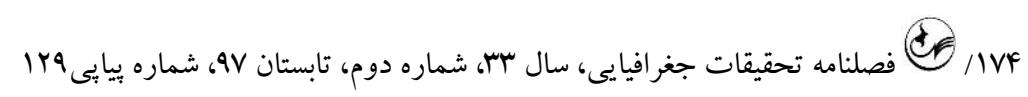

Shajeie, S. S. (2015). Forgotten identity in historical fabrics (case study: Historical fabric of Sabzevar). Paper presented at the National Conference on Native Architecture and Urban Planning of Iran, Yazd. (Persian)

Singer, T. (2010). Psyche \& the city, a Soul's guide to the modern metropolis. New Orleans, LA: Spring Journal. Williams, D. R., Patterson, M. E., Roggenbuck, J. W., \& Watson, A. E. (1992). Beyond the commodity metaphor: Examining emotional and symbolic attachment to place. Leisure sciences, 14(1), 29-46. [DOI:10.1080/01490409209513155]

Zanganeh, Y. (2002). An analysis of the factors affecting physical development and social-spatial construction of the city (case study: Sabzevar). (PhD), Tarbiat Modares University, Tehran. (Persian)

Zanganeh, Y., Hossein Abadi, S., Roshandel, T., \& Nabipoor, R. (2014). The impact of place spending and social capital on participatory improvement of Sabzevar old districts (case study: Sardeh neighborhood),. Urban Research and Planning, 5(19), 111-128. (Persian)

Zarghami, I., \& Aminian, M. (2012). Urban identity and landscape (case study of Pakdasht). Quarterly Journal of Islamic Studies, 3(9), 49-58. (Persian) 